\title{
Reproducible Planar Heterojunction Solar Cells Based on One-Step Solution-Processed Methylammonium Lead Halide Perovskites
}

Sai Bai, Nobuya Sakai, Wei Zhang, Zhiping Wang, J acob T.-W. Wang, Feng Gao and Henry J . Snaith

The self-archived postprint version of this journal article is available at Linköping University Institutional Repository (DiVA):

http:/ / urn.kb.se/ resolve?urn=urn:nbn:se:liu:diva-153804

N.B.: When citing this work, cite the original publication.

Bai, S., Sakai, N., Zhang, W., Wang, Z., Wang, J . T., Gao, F., Snaith, H.J ., (2017), Reproducible Planar Heterojunction Solar Cells Based on One-Step Solution-Processed Methylammonium Lead Halide

Perovskites, Chemistry of Materials, 29(1), 462-473. https:// doi.org/ 10.1021/ acs.chemmater.6b05159

Original publication available at:

https:/ / doi.org/ 10.1021/acs.chemmater.6b05159

Copyright: American Chemical Society

http:// pubs.acs.org/ 


\title{
Reproducible Planar Heterojunction Solar Cells Based on One-Step Solution-Processed Methylammonium Lead Halide Perovskites
}

Sai Bai, ${ }^{1,2}$ Nobuya Sakai, ${ }^{1}$ Wei Zhang, ${ }^{1,3}$ Zhiping Wang, ${ }^{1}$ Jacob T.-W. Wang, ${ }^{1}$ Feng Gao ${ }^{1,2 *}$ and Henry J. Snaith ${ }^{1 *}$

${ }^{1}$ Department of Physics, Clarendon Laboratory, University of Oxford, Parks Road, Oxford OX1 3PU, United Kingdom.

${ }^{2}$ Department of Physics, Chemistry and Biology (IFM), Linköping University, Linköping 58183, Sweden

${ }^{3}$ School of Chemistry, Joseph Banks Laboratories, University of Lincoln, Beevor Street, Lincoln LN6 7DL, United Kingdom

*E-mail: feng.gao@physics.ox.ac.uk (F.G.)

*E-mail: henry.snaith@physics.ox.ac.uk (H.S.)

\begin{abstract}
:
Metal halide perovskites have been demonstrated as one of the most promising materials for low-cost and high-performance photovoltaic applications. However, due to the susceptible crystallization process of perovskite films on planar substrates and the high sensitivity of the physical and optoelectronic nature of the internal interfaces within the devices, researchers in different laboratories still experience poor reproducibility in fabricating efficient perovskite solar cells with planar heterojunction device structures. In this method paper, we present detailed information on the reagents, equipment, and procedures for the fabrication of planar perovskite solar cells in both "regular" n-i-p and "inverted" $p-i-n$ architectures based on one-step solution-processed methylammonium lead triiodide $\left(\mathrm{MAPbI}_{3}\right)$ perovskite films. We discuss key parameters affecting the crystallization of perovskite and the device interfaces. This method paper will provide a guideline for the reproducible fabrication of planar heterojunction solar cells based on $\mathrm{MAPbI}_{3}$ perovskite films. We believe that the shared experience on MA-based perovskite films and planar solar cells will be also useful for the optimization process of perovskites with varied compositions, and other emerging perovskite-based optoelectronic devices.
\end{abstract}




\section{Introduction and Background}

Metal halide perovskites have come under the spotlight due to their great success in photovoltaic and energy applications during the past few years. ${ }^{1-6}$ As we show in Figure 1a, the perovskite materials have a general formula of $\mathrm{AMX}_{3}$, where $\mathrm{A}$ is an organic or alkali metal cation, $\mathrm{M}$ is a divalent metal cation, and $\mathrm{X}$ is a halogen anion that binds to both cations. Among these, methylammonium lead halide perovskites $\left(\mathrm{MAPbX}_{3}\right)$ are the most widely studied systems. Metal halide perovskites exhibit strong and easily tunable light absorption, excellent crystallinity, ambipolar charge transport, and long diffusion lengths for both electrons and holes. ${ }^{7-12}$ Furthermore, they can be easily processed from solutions using low-cost raw materials. These unique features make perovskite solar cells promising as a new generation of photovoltaics. With the intense worldwide efforts on the materials, film deposition methods, device architectures and interface engineering, the power conversion efficiency of perovskite solar cells has rocketed from an initial value of $3.8 \%$ to the current record of $22.1 \%$ within few years, representing the fastest acceleration in efficiency in the history of photovoltaics. $^{13-20}$

Device structures of perovskite solar cells can be generally classified into two major categories: mesoporous and planar heterojunction structures. The initial studies on perovskite solar cells were based on the concept of dye-sensitized solar cells with perovskite nanocrystals as the sensitizers. ${ }^{13,21}$ By replacing the problematic liquid electrolyte with a solid-state p-type (2'-7,7'-tetrakis(N,N-di-p-methoxyphenylamine)-9,9-spirobifluorene (spiro-OMeTAD) hole transporter, high-performance perovskite solar cells with increased 
stability can be achieved. ${ }^{22,23}$ Most of the early studies on perovskite solar cells focused on devices with mesoporous titanium oxide $\left(\mathrm{TiO}_{2}\right)$ or aluminum oxide $\left(\mathrm{Al}_{2} \mathrm{O}_{3}\right)$ scaffold. High-temperature derived compact $\mathrm{TiO}_{2}$ layer and p-type spiro-OMeTAD were used as the electron-transporting layer (ETL) and hole-transporting layer (HTL), respectively (as shown in Figure 1b). ${ }^{19,22}$ Further investigation revealed that perovskite materials exhibit ambipolar charge transport and long charge diffusion lengths, justifying the observation of high charge collection efficiency and high efficiency in devices constructed with a simplified planar architecture. $^{24-26}$

In a typical planar heterojunction solar cell, the perovskite light-harvesting layer is simply sandwiched between the ETL and HTL. Planar perovskite solar cells can be fabricated with the electron selective contact on the substrate side, or with the hole-selective contact on the substrate side. Throughout this manuscript, we will refer to cells with the electron-selective contact on the conducting oxide substrate side as n-i-p devices, and those inverted cells with the hole-selective contact on the substrate side as p-i-n cells. We give examples of such architectures in Figure 1c and 1d, respectively. Planar devices simplified the device architecture as well as the fabrication procedure of perovskite solar cells. In addition, extensive existing knowledge of hybrid interfaces in traditional thin film photovoltaics, such as copper indium gallium selenide (CIGS) and CdTe solar cells and especially in the research field of organic photovoltaics, can be utilized for interface optimization of these planar heterojunction perovskite solar cells. Moreover, the planar devices can be fabricated on large-area flexible substrates under low-temperature, which is desirable for the future 
high-throughput industrial production process. $^{27,28}$ The key feature of planar heterojunction, over its predecessor cell architectures incorporating a mesoporous scaffold, is that the light is absorbed and charge is generated in a solid non-porous perovskite thin film.

A key requirement in order to achieve efficient and reproducible planar heterojunction solar cell, is that the perovskite active layer should be uniform, continuous and "pin-hole free" to minimize "shunting" pathways. During the past few years, various deposition techniques including one-step coating, two-step deposition, vapor phase deposition and variations upon these methods have been developed to achieve a better control on the film quality of perovskites. $^{14,15,22,25,29-33}$ Through optimizing composition of precursors and deposition processes, more and more groups are now able to deposit high-quality perovskite thin films on various planar substrates using simple one-step coating methods. However, due to the complex crystallization process, which is highly susceptible to environmental conditions, the film quality of perovskite on different planar substrates exhibits large difference under varied deposition conditions. ${ }^{34-36}$ In addition, the electronic and physical nature of the internal heterojunctions within the perovskite solar cells are also important and require careful control and optimization for efficient and reproducible devices. Presently, many researchers in different laboratories still experience poor reproducibility of devices when they follow the reported experimental procedural descriptions in the literature, which hinders and slows the global progress of perovskite solar cells research. Therefore, it is essential to have a detailed and high-reproducible methodology for the fabrication of efficient planar perovskite solar cells. If a standard and reproducible "control cell" existed, it would also make fair comparison 
between different progress in different laboratories easier.

In this paper, we present detailed procedures for the fabrication of reproducible planar perovskite solar cells (n-i-p and p-i-n structures) based on one-step coating process. We use the benchmark $\mathrm{MAPbI}_{3}(\mathrm{Cl})$ perovskites fabricated from precursors composed of methylammonium iodide (MAI) and two different lead metal sources including lead chloride $\left(\mathrm{PbCl}_{2}\right)$ or lead acetate trihydrate $\left(\mathrm{Pb}(\mathrm{Ac})_{2} \cdot 3 \mathrm{H}_{2} \mathrm{O}\right)$ as the example to discuss key parameters for the fabrication of high-quality perovskite films. In addition, we point out and discuss the key processes affecting the device performance of perovskite solar cells and our optimization strategy. We provide detailed information about the reagents, equipment and deposition parameters for $\mathrm{PbCl}_{2}$ and $\mathrm{Pb}(\mathrm{Ac})_{2} \cdot 3 \mathrm{H}_{2} \mathrm{O}$ routes developed in our lab. We believe that this methods paper will be a useful guideline for the community to fabricate high-reproducible perovskite films and efficient planar solar cells based on one-step solution processed $\mathrm{MAPbI}_{3}$ perovskites.

\section{Conventional n-i-p perovskite solar cells fabricated from 3:1 $\mathrm{MAI}: \mathbf{P b C l}_{2}$ precursor}

The first embodiments of perovskite employed as light harvester in solar cells were fabricated from a precursor composed of stoichiometric $(1: 1)$ molar ratio of lead iodide $\left(\mathrm{PbI}_{2}\right)$ and $\mathrm{MAI}$ in $\gamma$-butyrolactone (GBL) or $N, N$-dimethylformamide (DMF). ${ }^{13}$ We undertook a significant deviation from this, by processing the perovskite films from excess MAI in combination with $\mathrm{PbCl}_{2}$. This lead to a "mixed halide" perovskite, $\mathrm{MAPbI}_{3-\mathrm{x}} \mathrm{Clx}$, with comparatively uniform surface morphology, and excellent crystallinity and electronic properties with long charge carrier lifetime and diffusion length. ${ }^{11,26,37}$ However, due to the slow crystallization with the 
presence of excess hygroscopic $\mathrm{MAI}(\mathrm{Cl})$ component, the thin film growth is sensitive to the deposition conditions, especially the ambient humidity. ${ }^{36}$ A certain amount of humidity actually appears to be beneficial. It has been reported that $\mathrm{MAPbI}_{3-\mathrm{x}} \mathrm{Cl}_{\mathrm{x}}$ perovskite films deposited under controlled relative humidity $(\sim 30 \%)$ exhibited enhanced optoelectronic properties with significantly reduced carrier recombination as compared to the films grown in dry conditions. ${ }^{38}$ Although the moisture can enhance the properties of perovskites, the relative humidity needs to be carefully controlled and high moisture results in poor surface morphology and fast decomposition of the perovskite films. ${ }^{36}$ In order to achieve a better control of the film formation process, we carry out all the film deposition process for $\mathrm{MAPbI}_{3-\mathrm{x}} \mathrm{Cl}_{\mathrm{x}}$ in a homemade dry-box (Figure $\mathrm{S} 1$ in the supporting information) with controlled humidity at $\sim 15 \%$.

\subsection{Deposition of high-quality perovskite films from 3:1 $\mathrm{MAI}: \mathrm{PbCl}_{2}$ precursor}

Even with spin-coating and curing in a controlled humidity atmosphere, we still observed incomplete coverage of perovskite films on planar substrates, which is non-ideal for planar devices. In this section, we will discuss two modified methods including "antisolvent-drenching" and "air-drying" assisted deposition for the fabrication of high-quality perovskites. The two modified deposition methods can significantly improve the surface coverage of perovskite films on planar substrates and result in improved device performance. The perovskite precursor solution was coated on a clean substrate by a consecutive two-step spin-coating process at 1200 and 2000 rounds per minute (r.p.m) for $25 \mathrm{~s}$ and $12 \mathrm{~s}$ under low humidity (15-20\%) condition. The acceleration is 500 and 1200 r.p.m/s 
for the first and second step spin-coating program, respectively. For antisolvent-drenching, $350 \mu \mathrm{l}$ toluene (for a $2.8 \times 2.8 \mathrm{~cm}$ substrate) was slowly (within $\sim 3 \mathrm{~s}$ ) and continuously dispensed onto the pre-crystallized perovskite film, starting at $5 \mathrm{~s}$ after the spin program ramped to 2000 r.p.m. and proceeding for about 7 s. The dispensing speed of the toluene needs to be carefully controlled and fast dispensing usually causes poor morphology of the obtained perovskite films. ${ }^{39}$ It appears that the precise dispensing rate and time, and stage in spin-coating depends strongly on the perovskite precursor composition. For new compositions a broad trial of dispensing at different stages in spinning, and dispensing at different rates needs to be undertaken. For the air-drying method, the as-spun film (same speed and ramp rates as above) was immediately dried by holding the film in front of the dry air inlet to the dry-box with the air flow at 30-40 pound/ square inch (psi) for $\sim 30 \mathrm{~s}$ to accelerate the early stage nucleation process. ${ }^{39}$ The drying time depends on the atmospheric condition in the dry-box and the distance between substrate and air outlet hole as well as the air flow rate. For our set-up, the optimized distance between the substrate and the dry air inlet hole of air blow is $\sim 10 \mathrm{~cm}$. For best uniformity of drying, the substrate should be gently rocked by hand in small circles of $\sim 5 \mathrm{~mm}$ radius while being blown dry. After blowing, the color of film turns reddish brown while a dark brown color implies over-drying of the films. We give more detailed procedure on the modified deposition methods in the supporting information.

In Figure 2a-c, we show the scanning electron microscope (SEM) images of perovskite films on $\mathrm{TiO}_{2}$ coated FTO substrates fabricated from three different deposition methods. The obtained perovskite films through antisolvent-drenching and air-drying assisted deposition 
methods exhibit more uniform grains and almost no pinholes throughout the whole film. We systematically investigated the optical images at different stages of the crystallization (i.e. the as-spun films and films annealed at $60{ }^{\circ} \mathrm{C}$ for $5 \mathrm{~min}$ ). Immediately after spin-coating, we observed the formation of yellow/transparent dendrites at room temperature for films deposited without any modification (Figure 2d). We assume that the yellow/clear dendrites are crystals of a chloride rich "precursor" phase. ${ }^{40}$ The brown color region, which we infer to be iodide-rich perovskite crystals, appear surround the dendrites after thermally annealing at $60{ }^{\circ} \mathrm{C}$ for $5 \mathrm{~min}$ (Figure $2 \mathrm{~g}$ ).

For the films processed with antisolvent-drenching, both brown and transparent crystals appeared in the films just after spin-coating (Figure 2e). Interestingly, in this case, the crystal centers are surrounded by transparent domains. During the annealing at $60{ }^{\circ} \mathrm{C}$ for $5 \mathrm{~min}$, the brown phase grows over the adjoining "chloride-rich" transparent phase giving rise to a large network of iodide rich perovskite crystals (Figure $2 \mathrm{~h}$ ). The air-drying method also produced both brown and transparent crystals just after spinning, but the density of brown crystals is lower than the toluene-assisted films (Figure 2f). During annealing $\left(60^{\circ} \mathrm{C}\right.$ for $\left.5 \mathrm{~min}\right)$, the behavior of crystal growth of both brown and transparent nucleation is similar to the toluene assisted film (Figure 2i). We conclude that the antisolvent-drenching and air-drying assisted methods are both helpful to produce more initial perovskite crystals, which could generate more continuous perovskite films after thermal annealing and polycrystalline film growth.

To demonstrate the degree to which the deposition methods influence the device performance, we fabricated conventional n-i-p planar heterojunction solar cells with the configuration of 
glass/FTO/compact $\mathrm{TiO}_{2} /$ perovskite/spiro-OMeTAD/Ag. Without any modification for the deposition of perovskite films, the obtained solar cells in dry-box exhibit poor device performance with a maximum efficiency of $10.7 \%$. Improved device performance with efficiencies of $15.9 \%$ and $17.6 \%$ can be achieved for devices based on antisolvent-drenching and air-drying assisted deposition, respectively. We show the J-V curves for the champion devices with perovskite films deposited from three different deposition methods in Figure 3a, and more detailed device performance characteristics are shown in Figure S2 in the supporting information. We note that perovskite solar cells, especially those with conventional planar (n-i-p) structure comprising a compact $\mathrm{TiO}_{2}$ electron selective contact, often exhibit anomalous hysteresis in the J-V curves. This results in a large difference between the power conversion efficiency estimated under different scan rates and in the forward and reverse scanning directions. ${ }^{41-43}$ The hysteresis problem makes it difficult to obtain universal and unambiguous characterization and comparison of the obtained device performance. In our previous reports, we suggested that the steady-state power output (SPO) measured at the maximum power point under working conditions should be given as a critical indicator to fully evaluate the device performance. ${ }^{41}$ As we show in Figure 3b, our champion devices fabricated from antisolvent-drenching and air-drying assisted deposition also exhibit a higher SPO of $\sim 14 \%$. As a comparison, the SPO is $\sim 7 \%$ for the champion device based on perovskite films derived from conventional deposition.

\subsection{Interface modification with fullerene for $n-i-p$ solar cells}

The interfaces between perovskite films and n-type charge extraction layers have a significant 
impact on the device hysteresis and long-term stability. As the most widely used ETL for perovskite solar cells, trap states and electronic defects in $\mathrm{TiO}_{2}$ have been reported to be a major contributor to slow electron transfer from the perovskite to the $\mathrm{TiO}_{2}$ at the interface, and poor ultraviolet light stability of devices. ${ }^{44,45}$ In addition, defects generated at the interface between the perovskite and the charge selective electrode could further contribute towards non-optimal operation. In previous reports from ourselves and others, we have shown that by modifying the n-type contact with a self-assembled fullerene monolayer, or thin films of fullerene $\left(\mathrm{C}_{60}\right)$ and fullerene derivatives, ${ }^{46-50}$ the electron extraction from perovskites to $\mathrm{TiO}_{2}$ can be greatly improved, and the device hysteresis can be significantly reduced, in addition to improved device stability. ${ }^{46,48}$ However, to achieve reproducible devices comprising $\mathrm{C}_{60}$ electron extraction layer, several key parameters need to be carefully optimized.

A well-dissolved solution is critical for the deposition of uniform $\mathrm{C}_{60}$ films on the substrates. We prepare the $\mathrm{C}_{60}$ solution $(\sim 10 \mathrm{mg} / \mathrm{ml})$ in the air with anhydrous 1,2-dichlorobenzene as the solvent. The solution is then kept under stirring at room temperature for over 6 hours in the glovebox to avoid the aggregation of $\mathrm{C}_{60}$. Heating the solution at $60{ }^{\circ} \mathrm{C}$ prior to use is helpful to the dissolving process but the solution needs to be cooled down to room temperature before spin-coating. As we just need a thin layer (several tens of nanometers) of the $\mathrm{C}_{60}$ film as the ETL, the surface roughness of substrate has a big influence on the morphology of final deposited film. We find that $\mathrm{C}_{60}$ layers deposited on rough FTO substrates (TEC 7, Pilkington) show non-uniform and discontinuous morphology. This can be simply identified by seeing 
small aggregates on the surface directly after spin coating, and/or obvious discontinuous morphology after thermal annealing of perovskite films. By employing FTO substrates (TEC15, Pilkington) with a lower roughness and improving the surface wettability with oxygen plasma treatment right before perovskite film deposition, we can obtain uniform $\mathrm{C}_{60}$ layers with full coverage on the substrates.

In addition to uniformity, the thickness of the $\mathrm{C}_{60}$ film is closely associated with the electron-transporting properties and therefore needs to be carefully optimized. We show the $\mathrm{J}-\mathrm{V}$ curves of champion devices with a range of $\mathrm{C}_{60}$ film thickness in Figure $3 \mathrm{c}$, d. With a $\mathrm{C}_{60}$ film deposited at 1500 r.p.m (which gives an as deposited film thickness $\sim 30 \mathrm{~nm}$ ), we observe a significantly improved short-circuit current (Jsc) as well as fill factor (FF), in comparison to the devices with solely $\mathrm{TiO}_{2}$ electron extraction layers. We were able to obtain a champion efficiency of $17.9 \%$ with the highest SPO of $16.4 \%$. A higher spin-coating speed (above 2000 r.p.m) always generates a discontinuous $\mathrm{C}_{60}$ layer on the substrate, which results in exaggerated hysteresis in the $\mathrm{J}-\mathrm{V}$ curves and lower overall efficiency.

\section{Lead acetate trihydrate precursor for conventional planar solar cells}

As shown in previous sections and many other reports, without additional treatment, it is still challenging to obtain pinhole-free perovskite thin films by one-step solution processing based on traditional lead halide precursor solutions $\left(\mathrm{PbCl}_{2}\right.$ or $\mathrm{PbI}_{2}$ mixed with MAI in DMF). Over the last two years we have introduced a route to fabricate $\mathrm{MAPbI}_{3}$ perovskite films with non-halide lead precursors, and specifically lead acetate trihydrate $\left(\mathrm{Pb}(\mathrm{Ac})_{2} \cdot 3 \mathrm{H}_{2} \mathrm{O}\right)$, as the starting material in the precursor. ${ }^{33}$ We systematically investigated lead salts with varied 
anions $\left(\mathrm{PbCl}_{2}, \mathrm{PbI}_{2}, \mathrm{~Pb}(\mathrm{Ac})_{2} \cdot 3 \mathrm{H}_{2} \mathrm{O}\right.$ and $\left.\mathrm{Pb}\left(\mathrm{NO}_{3}\right)_{2}\right)$ and found that the anions in the perovskite solution have an enormous influence upon perovskite crystallization kinetics and film formation. ${ }^{51}$ By using $\mathrm{Pb}(\mathrm{Ac})_{2} \cdot 3 \mathrm{H}_{2} \mathrm{O}$ as the starting material in the precursor, the crystal growth of perovskites was speeded up significantly, enabling formation of ultra-smooth and pinhole-free perovskite films through a simple one-step solution coating after $\sim 5$ min thermal annealing. In this section, we will discuss the effect of different lead precursors, mainly focusing on lead acetate trihydrate, on perovskite crystallization kinetics, thin film morphology and the obtained device performance.

\subsection{High-quality perovskite films deposited from $\mathrm{Pb}(\mathrm{Ac})_{2} \cdot 3 \mathrm{H}_{2} \mathrm{O}$ precursor}

The transition of perovskite precursors into thin films typically involves the evaporation of solvent, sublimation/evaporation of the by-products (e.g. $\mathrm{CH}_{3} \mathrm{NH}_{3} \mathrm{X}, \mathrm{X}=\mathrm{Cl}, \mathrm{I}, \mathrm{Ac}$ ), crystal nucleation and growth, etc., which can be described as follows:

$\mathrm{PbX}_{2}+3 \mathrm{CH}_{3} \mathrm{NH}_{3} \mathrm{I} \rightarrow \mathrm{CH}_{3} \mathrm{NH}_{3} \mathrm{PbI}_{3}+2 \mathrm{CH}_{3} \mathrm{NH}_{3} \mathrm{X}(\mathrm{X}=\mathrm{Cl}, \mathrm{I}, \mathrm{Ac})$

We employed in-situ wide-angle X-ray scattering (WAXS) to probe the evolution of the perovskite crystal formation using precursors with different lead salts as the starting materials, as shown in Figure 4a-c. Crystallization kinetics of the systems are assessed by tracking key "precursor state" peaks (blue stick markers on the bottom-most) and defining $t_{\text {end }}$ as the time when all "precursor state" peaks are gone, representing complete perovskite transformation. We clearly observed that the required annealing time, as indicated by the $t_{\text {end }}$, is much shorter for perovskites made from $\mathrm{Pb}(\mathrm{Ac})_{2} \cdot 3 \mathrm{H}_{2} \mathrm{O}$ route than $\mathrm{PbCl}_{2}$ and $\mathrm{PbI}_{2}$ routes. We correlate this observation to the ease with which the by-product can be removed during perovskite film 
formation. This was further confirmed by thermal gravimetric analysis (TGA) characterizations for the by-products of $\mathrm{CH}_{3} \mathrm{NH}_{3} \mathrm{X}(\mathrm{X}=\mathrm{Cl}$, I, Ac). The initial decomposition temperatures (defined by $\mathrm{T}$ at $95 \%$ weight) show a trend of $\mathrm{T}_{\mathrm{CH} 3 \mathrm{NH} 3 \mathrm{Ac}}\left(97.4{ }^{\circ} \mathrm{C}\right) \ll \mathrm{T}_{\mathrm{CH} 3 \mathrm{NH} 3 \mathrm{Cl}}$ $\left(226.7{ }^{\circ} \mathrm{C}\right)<\mathrm{T}_{\mathrm{CH} 3 \mathrm{NH} 3 \mathrm{I}}\left(245.0{ }^{\circ} \mathrm{C}\right)$, clearly demonstrating that the $\mathrm{CH}_{3} \mathrm{NH}_{3} \mathrm{Ac}$ is thermally unstable and much easier to be removed than $\mathrm{CH}_{3} \mathrm{NH}_{3} \mathrm{Cl}$ and $\mathrm{CH}_{3} \mathrm{NH}_{3} \mathrm{I}^{33}$ Thus, at the same annealing temperature, the growth rate is much higher for the films processed from $\mathrm{Pb}(\mathrm{Ac})_{2} \cdot 3 \mathrm{H}_{2} \mathrm{O}$, which tends to form a large amount of relatively smaller crystals on a short time scale. For more details of the effect of anions on perovskite crystallization kinetics, we refer the readers to a recent work done by Moore and co-workers. ${ }^{51}$

Here, we illustrate the surface property of perovskite films deposited from different lead precursors on compact $\mathrm{TiO}_{2}$ coated FTO substrates. These films are made by simple spin-coating (without any air-drying and antisolvent drenching) in a nitrogen filled glove box. As can be seen from the top-view SEM images, the perovskite films made from $\mathrm{PbCl}_{2}$ (Figure 4d) and $\mathrm{PbI}_{2}$ (Figure 4e) routes are non-continuous with pinholes whereas thin films deposited from $\mathrm{Pb}(\mathrm{Ac})_{2} \cdot 3 \mathrm{H}_{2} \mathrm{O}$ (Figure $4 \mathrm{f}$ ) route exhibit a full coverage on the substrates without any pinhole. As shown in the insets of closer observations, the $\mathrm{PbCl}_{2}$ precursor leads to crystalline platelets to be in tens of micrometer length scale whereas for the $\mathrm{PbI}_{2}$ route and the $\mathrm{Pb}(\mathrm{Ac})_{2} \cdot 3 \mathrm{H}_{2} \mathrm{O}$ route, crystal grains are around a few hundred $\mathrm{nm}$ to one micrometer in size. In addition, from the cross-section SEM images, we observe that $\mathrm{Pb}(\mathrm{Ac})_{2} \cdot 3 \mathrm{H}_{2} \mathrm{O}$ route achieves much smoother perovskite thin films than that made from $\mathrm{PbCl}_{2}$ and $\mathrm{PbI}_{2}$ routes. Our previous atomic force microscopy (AFM) study of perovskite thin films confirmed a root mean squared 
(RMS) roughness of $12.3 \mathrm{~nm}$ for $\mathrm{Pb}(\mathrm{Ac})_{2} \cdot 3 \mathrm{H}_{2} \mathrm{O}$ route on the scale of $15 \mu \mathrm{m} \times 15 \mu \mathrm{m}$, as opposed to 62.4 and $52.2 \mathrm{~nm}$ for $\mathrm{PbCl}_{2}$ and $\mathrm{PbI}_{2}$ routes, respectively. ${ }^{33}$

\subsection{Conventional planar solar cells fabricate from $\mathrm{Pb}(\mathrm{Ac})_{2} \cdot 3 \mathrm{H}_{2} \mathrm{O}$ precursor}

We compare the devices with perovskite films deposited from different lead sources described above in conventional n-i-p planar heterojunction solar cells. To achieve the best device performance, we optimized the annealing temperature and annealing time for each particular route and all the deposition process of perovskite precursors were carried out in the glovebox. Note that, to keep the atmosphere clean and constant for each batch of devices, we purge the glovebox before we start a new spin-coating process. The total purging time depends on the spin-coating time used by the former user, which is usually 10 min purging after 20 min spin-coating. The optimized conditions (annealing temperature/time) are $100{ }^{\circ} \mathrm{C} / 2 \mathrm{~h}, 150{ }^{\circ} \mathrm{C}$ /40min, and $100{ }^{\circ} \mathrm{C} / 5 \mathrm{~min}$ for $\mathrm{PbCl}_{2}, \mathrm{PbI}_{2}$ and $\mathrm{Pb}(\mathrm{Ac})_{2} \cdot 3 \mathrm{H}_{2} \mathrm{O}$ precursor, respectively. The average power conversion efficiency with optimized conditions are 12.0, 9.3 and $14.0 \%$ based on perovskites deposited from $\mathrm{PbCl}_{2}, \mathrm{PbI}_{2}$ and $\mathrm{Pb}(\mathrm{Ac})_{2} \cdot 3 \mathrm{H}_{2} \mathrm{O}$ routes, respectively. We also found that the SPO of the champion cell fabricated from $\mathrm{Pb}(\mathrm{Ac})_{2} \cdot 3 \mathrm{H}_{2} \mathrm{O}$ precursor was improved to $\sim 13.4 \%$, which is $88 \%$ of the highest scanned efficiency. As a comparison, the SPO is around 74 and $64 \%$ of the scanned efficiency for $\mathrm{PbCl}_{2}$ and $\mathrm{PbI}_{2}$, respectively. Therefore, $\mathrm{Pb}(\mathrm{Ac})_{2} \cdot 3 \mathrm{H}_{2} \mathrm{O}$ precursor enables not only much faster and more uniform crystallization but also improved device performance over the other two routes and good reproducibility of the results, as indicated by the smaller standard deviation of solar cell performance parameters. The major reason that leads to improved device efficiency via 
$\mathrm{Pb}(\mathrm{Ac})_{2} \cdot 3 \mathrm{H}_{2} \mathrm{O}$ route is due to the enhancement of open-circuit voltage $\left(\mathrm{V}_{\mathrm{OC}}\right)$, and the trend of average $\mathrm{V}_{\text {oc }}$ as $\mathrm{PbI}_{2}(0.85 \mathrm{~V}) \sim \mathrm{PbCl}_{2}(0.88 \mathrm{~V})<\mathrm{Pb}(\mathrm{Ac})_{2} \cdot 3 \mathrm{H}_{2} \mathrm{O}(0.99 \mathrm{~V})$. This can be attributed to a reduction in the contact area between p-type spiro-OMeTAD and n-type $\mathrm{TiO}_{2}$ compact layer, originating from the non-continuous perovskite films made from $\mathrm{PbCl}_{2}$ and $\mathrm{PbI}_{2}$ routes. These pin-holes in the perovskite films lead to reduced shunt resistance in the devices, which we term "shunting".

As a follow-up work, we further found that the film quality made from $\mathrm{Pb}(\mathrm{Ac})_{2} \cdot 3 \mathrm{H}_{2} \mathrm{O}$ route can be significantly enhanced by adding an additive, hypophosphorous acid (HPA), in the precursor solution. HPA is commonly added as a stabilizer in commercial hydroiodic acid, which is one of the starting materials to synthesize MAI but is purified by recrystallization of the final product. During the optimization of $\mathrm{Pb}(\mathrm{Ac})_{2} \cdot 3 \mathrm{H}_{2} \mathrm{O}$ routes, we noticed that our best solar cell results were always obtained when the MAI was dried but not purified via recrystallization following the synthesis. We realized that some 'impurity' left in the as-synthesized MAI should have a beneficial influence on the perovskite film formation. We found that the HPA additive in $\mathrm{Pb}(\mathrm{Ac})_{2} \cdot 3 \mathrm{H}_{2} \mathrm{O}$ precursor has no effect on the pin-hole free nature but significantly improved the optoelectronic properties of the perovskite films via reducing the defect densities, estimated from $1.58 \times 10^{16}$ to $3.25 \times 10^{15} \mathrm{~cm}^{-3}$, by a factor of around 5. During the optimization process of our solar cell devices, we noticed that the film quality and device performance were significantly influenced by the precursor and processing conditions. The precursor with $30 \mathrm{wt} \%$ concentration (calculated based on the sum of chemicals in the solution) gave the best device performance. With higher precursor 
concentration $(\sim 40 \mathrm{wt} \%)$, the obtained films became hazy and non-uniform, resulting in significantly decreased device performance. ${ }^{32}$ This may result from the drying process of precursor solution on substrates during the spincoating, which we will discuss in the next section. The HPA concentration in the precursor also need to be optimized and we found that the molar ratio of $7.5 \%$ for $\mathrm{HPA} / \mathrm{Pb}(\mathrm{Ac})_{2} \cdot 3 \mathrm{H}_{2} \mathrm{O}(3 \mu \mathrm{lin} 1 \mathrm{ml} 30 \mathrm{wt} \%$ precursor) gave the best device performance. Moreover, we need to mention that a drying process $\sim 10$ min (drying time depends on the atmosphere in the glovebox) after spin-coating is necessary to get reproducible mirror-like perovskite films and efficient devices on $\mathrm{TiO}_{2}$ substrates. In addition, we found best device results when we use the solution immediately after adding the HPA in the precursor. By optimizing the composition of precursors and the film deposition process, we could obtain devices with an average efficiency over $15 \%$ with a small standard deviation of solar cell performance parameters, using the commercially available MAI.

\section{Inverted planar solar cells fabricated from $\mathrm{Pb}(\mathrm{Ac})_{2} \cdot 3 \mathrm{H}_{2} \mathrm{O}$ route}

It has been demonstrated the hysteresis in the current-voltage characteristics of perovskite solar cells can be successfully suppressed or even eliminated with inverted $\mathrm{p}-\mathrm{i}-\mathrm{n}$ planar device structure by selecting proper fullerene-based electron transport materials on top of perovskite films. $^{31,52}$ In a typical inverted device structure, poly(3,4-ethylenedioxythiophene):poly(styrene-sulfonate) (PEDOT:PSS) and [6,6]-phenyl C61-butyric acid methyl ester (PCBM) are commonly used as p-type and n-type charge transport layers. Previous reports have pointed out that the PCBM layer can efficiently passivate the trap states in the perovskite films and reduce the charge recombination at grain 
boundaries as well as the electrode interface, eliminating hysteresis and leading to improved device performance. ${ }^{52}$ Due to its low conductivity, the thickness of PCBM layer should be thin enough to act as efficient ETL and minimize the series resistance. However, a thin PCBM layer usually causes incomplete surface coverage on rough perovskite films, resulting in large leakage current and decreased device performance. ${ }^{53}$ Perovskite films deposited from $\mathrm{Pb}(\mathrm{Ac})_{2} \cdot 3 \mathrm{H}_{2} \mathrm{O}$ precursor exhibit ultra-smooth and pin-hole free film properties, which makes this route ideal for the fabrication of efficient inverted planar perovskite solar cells. In this section, we will provide detailed recipe for the fabrication of reproducible inverted planar devices based on $\mathrm{Pb}(\mathrm{Ac})_{2} \cdot 3 \mathrm{H}_{2} \mathrm{O}$ precursor, and then follow on to discuss the influence of hydration of $\mathrm{Pb}(\mathrm{Ac})_{2}$.

\subsection{Key parameters for reproducible inverted planar solar cells}

\subsubsection{Deposition of high-quality perovskite films on PEDOT:PSS substrates}

For inverted planar p-i-n solar cells, we carried out all the optimization on PEDOT:PSS coated indium tin oxide (ITO) substrates. Figure 5a shows the typical inverted planar device structure, in which solution processed bathocuproine (BCP) is used as an interface modifier, to improve the electronic contact between the fullerene and the metal electrode. ${ }^{54}$ Except the deposition and thermal annealing $\left(150^{\circ} \mathrm{C}\right.$ for $\left.10 \mathrm{~min}\right)$ of PEDOT:PSS, all other processes were carried out in an $\mathrm{N}_{2}$-filled glovebox $\left(\sim 10 \mathrm{ppm}_{2},<1 \mathrm{ppm} \mathrm{H}_{2} \mathrm{O}\right)$. As we clarified before, HPA with re-optimized concentration $(\sim 4.5 \mu \mathrm{HPA}$ in $1 \mathrm{ml}$ precursor solution) is used as an additive in the precursor.

During the optimization of inverted solar cells, we noticed that the final device performance is 
extremely sensitive to spin-coating conditions. The evaporation speed of organic solvent during the spin-coating process plays a critical role to obtain high-quality perovskite films and high-performance inverted planar solar cells based on $\mathrm{Pb}(\mathrm{Ac})_{2} \cdot 3 \mathrm{H}_{2} \mathrm{O}$ route. As we show in Figure $5 \mathrm{~b}$, we found that a lower acceleration of the spin-coating process is more favorable to get higher average device efficiency, and $\sim 8 \mathrm{~s}$ is the most suitable ramp time for the spin-coating speed of 2000 r.p.m. In addition, due to the existence of a top hole in the lid of our spin-coater (as shown in Figure S3a in the supporting information), intense $\mathrm{N}_{2}$ flow generated during the spin-coating process could speed up the solvent evaporation and affect the formation of perovskite films. A similar phenomenon has also been reported by Huang et al., who developed a gas assisted deposition method for the fabrication of smooth $\mathrm{MAPbI}_{3}$ films employing precursor composed of $\mathrm{MAI}$ and $\mathrm{PbI}_{2}$ with 1:1 molar ratio. ${ }^{55}$ However, for the $\mathrm{Pb}(\mathrm{Ac})_{2} \cdot 3 \mathrm{H}_{2} \mathrm{O}$ precursor, although the obtained perovskite film was dense and uniform with the $\mathrm{N}_{2}$ flow from the top hole, the device performance is poor due to the fast drying of the precursor (Figure S3b in the supporting information ). Based on this understanding, we have compared two kinds of different spin-coating processes with the lid open and totally closed (top hole blocked) to slow down the solvent evaporation. Inverted planar solar cells fabricated under these two spin-coating processes exhibited obviously improved device performance because of the slower solvent evaporation speed. We noted that under the lid-closed condition, the existed DMF vapor in the chamber of spin-coater is more helpful on improving the device reproducibility due to the further suppressed solvent evaporation.

Interestingly, by properly controlling the solvent evaporation process, we were able to obtain 
high-quality thin films on PEDOT:PSS using precursors with higher concentration and lower spin-coating speed (Figure 5c), which generates hazy films in our previous experiments with common spin-coating process. We also noticed that, for the processing of high-concentration precursors, slowing down the drying process after spin-coating was no longer helpful but detrimental to the obtained perovskite films. We need to put the samples on the preheated hot plate $\left(100^{\circ} \mathrm{C}\right)$ immediately after the spin-coating; otherwise the films become hazy even after $\sim 1$ min drying. By using a precursor solution with $0.8 \mathrm{M} \mathrm{Pb}(\mathrm{Ac})_{2} \cdot 3 \mathrm{H}_{2} \mathrm{O}$ and $2.4 \mathrm{M}$ MAI (solids in total $\sim 42 \mathrm{wt} \%$ ) in DMF under the optimized spin-coating, drying and annealing process, we can obtain highly reproducible p-i-n planar devices with efficiency over $15 \%$. In addition, we observed negligible hysteresis of the devices (Figure 5d).

\subsubsection{Interface engineering for inverted planar solar cells}

The interfaces, especially the cathode interface is crucial to get efficient and reproducible p-i-n planar perovskite solar cells. As the most widely used ETL in inverted structure, it is convenient to deposit PCBM layer with optimal coverage and thickness through tuning the solution concentration and the spin-coating speed. In addition to the thickness and coverage, it has been demonstrated that post-treatment of PCBM layer is essential to get efficient inverted devices. It has been reported that, due to the thermal instability of $\mathrm{MAPbI}_{3}$ perovskites, any post-annealing process at a temperature above $100{ }^{\circ} \mathrm{C}$ was possible to cause perovskite decomposition and result in a decrease of the charge carrier diffusion lengths. ${ }^{53,56}$ And hence, in most of the previous studies on inverted $\mathrm{p}-\mathrm{i}-\mathrm{n}$ perovskite solar cells, researchers tried to avoid thermal treatment after the deposition of perovskite films. However, Huang and 
co-workers have proposed that the infiltration of the PCBM molecule into the perovskite layer under thermal annealing at $100{ }^{\circ} \mathrm{C}$ can significantly improve the device performance. ${ }^{52}$ The authors attributed the device improvement to more efficient passivation by PCBM upon the large density of traps in perovskite films during the thermal annealing. With enhanced crystallinity and reduced energetic disorder of PCBM by solvent annealing (during the thermal annealing) treatment, the device performance can be further improved. ${ }^{57}$ These results indicate that the interface between the perovskite and the electron transport layer need to be carefully optimized.

During the optimization of inverted device structures based on $\mathrm{Pb}(\mathrm{Ac})_{2} \cdot 3 \mathrm{H}_{2} \mathrm{O}$ precursor, we also noticed that mild thermal annealing process of PCBM is helpful to obtain a better electron transport interface. For our inverted devices, a post-annealing treatment at $100{ }^{\circ} \mathrm{C}$ after PCBM deposition significantly improved the device performance. Figure S4 shows the influence of thermal annealing treatment of PCBM layer on the device performance. We found that without post-annealing on PCBM, J-V curves of the obtained devices exhibit low device efficiency with low Jsc and FF, suggesting poor charge extraction interface. The highest average device efficiency could be obtained after 10 min thermal annealing treatment at $100{ }^{\circ} \mathrm{C}$, while prolonged thermal annealing time resulted in decreased device performance, which can be attributed to the decomposition of the instable perovskite films.

The sensitive interface between PCBM and the metal electrode also needs to be further modified to obtain reproducible inverted planar devices and to avoid the quick degradation of devices after air exposure. It has been demonstrated that the oxygen and water in the air will 
be adsorbed on the surface of PCBM and resulting in rapid degradation of the PCBM/metal contact. Introducing a thin protective layer such as $\mathrm{BCP}$ or n-type metal oxide $\left(\mathrm{ZnO}, \mathrm{TiO}_{2}\right.$ and $\mathrm{Cr}_{2} \mathrm{O}_{3}$ ) on top of PCBM can greatly improve the device reproducibility and stability. ${ }^{28,35,53,58}$ In our devices, we employed a solution-processed BCP thin layer to achieve a better cathode interface. Isopropanol (IPA), which has negligible influence upon the perovskite films, was chosen as the solvent and the concentration of BCP solution was optimized and fixed at $\sim 0.5$ $\mathrm{mg} / \mathrm{ml} .{ }^{54}$ Due to the poor solubility of BCP in IPA, heating $\left(\sim 100{ }^{\circ} \mathrm{C}\right.$ for $\left.1 \mathrm{~h}\right)$ is necessary to get a completely dissolved solution. We note that although $\mathrm{BCP}$ results in efficient and reproducible devices, it is likely to introduce long-term stability issues.

\subsection{Controllable water content in $\mathrm{Pb}(\mathrm{Ac})_{2}$ for reproducible devices}

\subsubsection{Dehydration of lead acetate trihydrate}

Due to the easy-weathering property of $\mathrm{Pb}(\mathrm{Ac})_{2} \cdot 3 \mathrm{H}_{2} \mathrm{O}$, the varied hydration water over time makes it difficult to precisely control the water content and stoichiometric ratio of chemicals in the precursor. For example, we compared the as received $\mathrm{Pb}(\mathrm{Ac})_{2} \cdot 3 \mathrm{H}_{2} \mathrm{O}$ materials in different bottles with the same product no. from Sigma-Aldrich and found obvious difference in the obtained devices even under the same recipe (Figure S5a in the supporting information). Even in the same bottle, the materials exhibit different crystals property with large crystals and small grain powders coexisting (Figure $5 \mathrm{~b}$ in the supporting information). To achieve a better control of the precursors, totally dehydrated $\mathrm{Pb}(\mathrm{Ac})_{2}$ synthesized from physical and chemical methods have been used in previous research works on $\mathrm{Pb}(\mathrm{Ac})_{2}$ routes. ${ }^{59-62} \mathrm{As}$ reported, dehydrated $\mathrm{Pb}(\mathrm{Ac})_{2}$ could be obtained by drying the $\mathrm{Pb}(\mathrm{Ac})_{2} \cdot 3 \mathrm{H}_{2} \mathrm{O}$ under nitrogen 
or vacuum at a temperature higher than its melting point $\left(75^{\circ} \mathrm{C}\right)$. The dehydration can also be carried out by dissolving the $\mathrm{Pb}(\mathrm{Ac})_{2} \cdot 3 \mathrm{H}_{2} \mathrm{O}$ in methoxyethanol or methoxyethanol-xylene mixture and distilling the water repeatedly at high temperature (above $90{ }^{\circ} \mathrm{C}$ ). ${ }^{63}$ However, the incomplete elimination of water and the by-products (e.g. oxoproducts) due to the decomposition of $\mathrm{Pb}(\mathrm{Ac})_{2} \cdot 3 \mathrm{H}_{2} \mathrm{O}$ under high temperature will introduce more complicated and uncertain factors for the perovskite precursors. To date, the reaction of $\mathrm{Pb}(\mathrm{Ac})_{2} \cdot 3 \mathrm{H}_{2} \mathrm{O}$ with acetic anhydride is the most efficient dehydration technique and has been used in several recent reports to synthesize dehydrated $\mathrm{Pb}(\mathrm{Ac})_{2}$. The reaction of the dehydration process can be described as follows:

$\mathrm{Pb}\left(\mathrm{CH}_{3} \mathrm{COO}\right)_{2} \cdot 3 \mathrm{H}_{2} \mathrm{O}+3\left(\mathrm{CH}_{3} \mathrm{CO}\right)_{2} \mathrm{O} \rightarrow \mathrm{Pb}\left(\mathrm{CH}_{3} \mathrm{COO}\right)_{2}+6 \mathrm{CH}_{3} \mathrm{COOH}$

We provide detailed processes for the dehydration of $\mathrm{Pb}(\mathrm{Ac})_{2} \cdot 3 \mathrm{H}_{2} \mathrm{O}$ in the procedure section of supporting information. According to the characterization results from Fourier Transform Infrared Spectroscopy (FTIR) (Figure 6a), there is almost no obvious broad peak corresponding to the hydroxyl groups in the dehydrated samples, suggesting efficient elimination of the hydration water after the reaction. Moreover, there is no side reaction during the dehydration process based on acetic anhydride route and this can guarantee high purity of the final obtained dehydrated products.

\subsubsection{Optimal water content in the precursor for reproducible inverted devices}

We fabricated inverted p-i-n planar devices by employing the precursors composed of MAI and $\mathrm{Pb}(\mathrm{Ac})_{2} / \mathrm{Pb}(\mathrm{Ac})_{2} \cdot 3 \mathrm{H}_{2} \mathrm{O}$. However, we observed no major difference upon the device performance for devices fabricated from $\mathrm{Pb}(\mathrm{Ac})_{2} \cdot 3 \mathrm{H}_{2} \mathrm{O}$ and dehydrated $\mathrm{Pb}(\mathrm{Ac})_{2}$ starting 
materials. We estimate that in $1 \mathrm{ml}$ precursor composed of $0.8 \mathrm{M} \mathrm{Pb}(\mathrm{Ac})_{2} \cdot 3 \mathrm{H}_{2} \mathrm{O}$, the total water content in the solution is around $45.5 \mu \mathrm{l} / \mathrm{ml}(2.25 \mu \mathrm{l}$ from the HPA additive). We believe that the water molecule in the precursor has a significant influence on the crystallization process of perovskites, which has been also demonstrated by several other reports. ${ }^{64-67}$ To further quantify the optimal water content and achieve a better control of the devices fabricated from $\mathrm{Pb}(\mathrm{Ac})_{2}$ route, we systemically investigated the influence of water content on the device performance. In Figure 6b, we show the device performance parameters from the same batch solar cells based on perovskite films deposited from precursor with a range of water content. We observed a clear trend of enhancement on the device performance with the introduction of deionized water range from 0 to $20 \mu \mathrm{l}$ in $1 \mathrm{ml}$ perovskite precursor solution, while further increased water content resulted in decreased device efficiency. With the incorporation of water in the precursor, all device parameters including the $\mathrm{J}_{\mathrm{SC}}, \mathrm{V}_{\mathrm{OC}}$ and FF increased and we achieved a champion efficiency of $17.1 \%$ and an average efficiency over $16 \%$ with optimal water content of $20 \mu \mathrm{l}$ (Figure $6 \mathrm{c}$ ). Note that there was almost no hysteresis in the J-V curves of the obtained inverted devices. As we show in Figure 6d, the SPO (16.9\%) was almost the same as the highest scanned efficiency of our champion device.

\section{Conclusion and outlook}

In this methods paper, we have presented detailed recipes for the fabrication of high-efficiency and reproducible planar heterojunction (n-i-p and p-i-n structures) perovskite solar cells based on one-step solution-processed $\mathrm{MAPbI}_{3}$ perovskites deposited from $\mathrm{PbCl}_{2}$ and $\mathrm{Pb}(\mathrm{Ac})_{2} \cdot 3 \mathrm{H}_{2} \mathrm{O}$ precursors. Importantly, we have highlighted some of the peculiar 
influencing factors, including processing methodology and solution compositions, which have to be considered and optimized when fabricating the solar cells. In addition, due to the excellent charge transport and light emission properties of metal halide perovskites, other optoelectronic applications, such as photodetectors, light-emitting diodes (LEDs), lasers, etc. also experienced fast development recently. We hope that our detailed methodology for perovskite films and planar solar cells provided in this paper is also helpful for these emerging applications.

\section{ASSOCIATED CONTENT}

\section{Supporting information}

Detailed information of all reagents we use for the perovskite precursor and solar cells, all procedure including the preparation of substrates, preparation and deposition of perovskite precursors, bottom and top charge transport layers, deposition of electrodes and solar cell characterization, key parameters optimized for perovskite film deposition, photograph of the drybox and spincoater in our lab, more detailed characterization results of devices fabricated from $\mathrm{PbCl}_{2}$ and $\mathrm{Pb}(\mathrm{Ac})_{2} \cdot 3 \mathrm{H}_{2} \mathrm{O}$ precursor.

\section{ACKNOWLEDGMENTS}

This work was funded by grants EP/P02484X/1, EP/M024881/1, EP/M015254/1, EP/M014797/1, EP/M005143/1, EP/M023532/1 and EP/L024667/1 from the UK engineering and Physical Sciences Research Council (EPSRC), the Supergen Super Solar project, and the Carl Tryggers Stiftelse. S.B. is a VINNMER Fellow and Marie Skłodowska-Curie Fellow. 
(a)

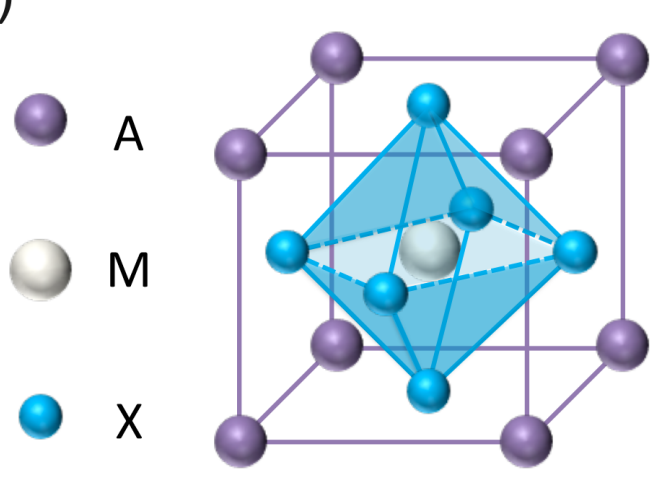

(c)

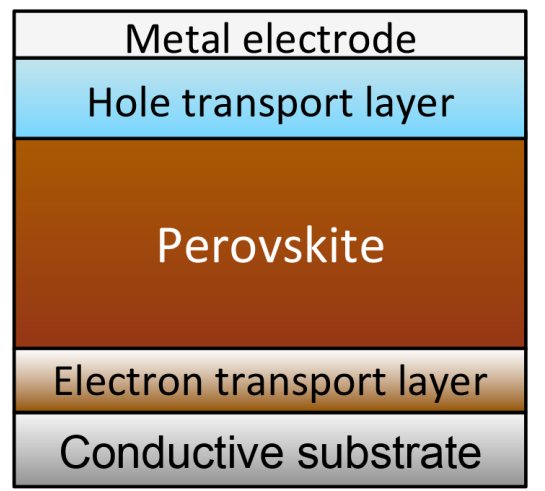

(b)

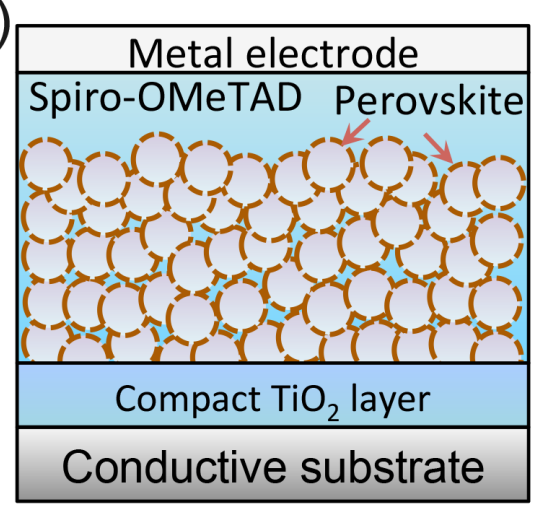

(d)

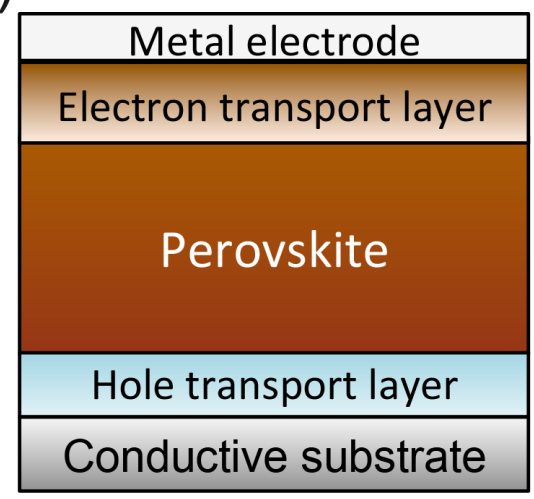

Figure 1: (a) The crystal structure of typical $\mathrm{AMX}_{3}$ metal halide perovskite. The schematic diagram of perovskite solar cells with mesoporous structure (b), conventional n-i-p (c) and inverted p-i-n planar structure (d). 

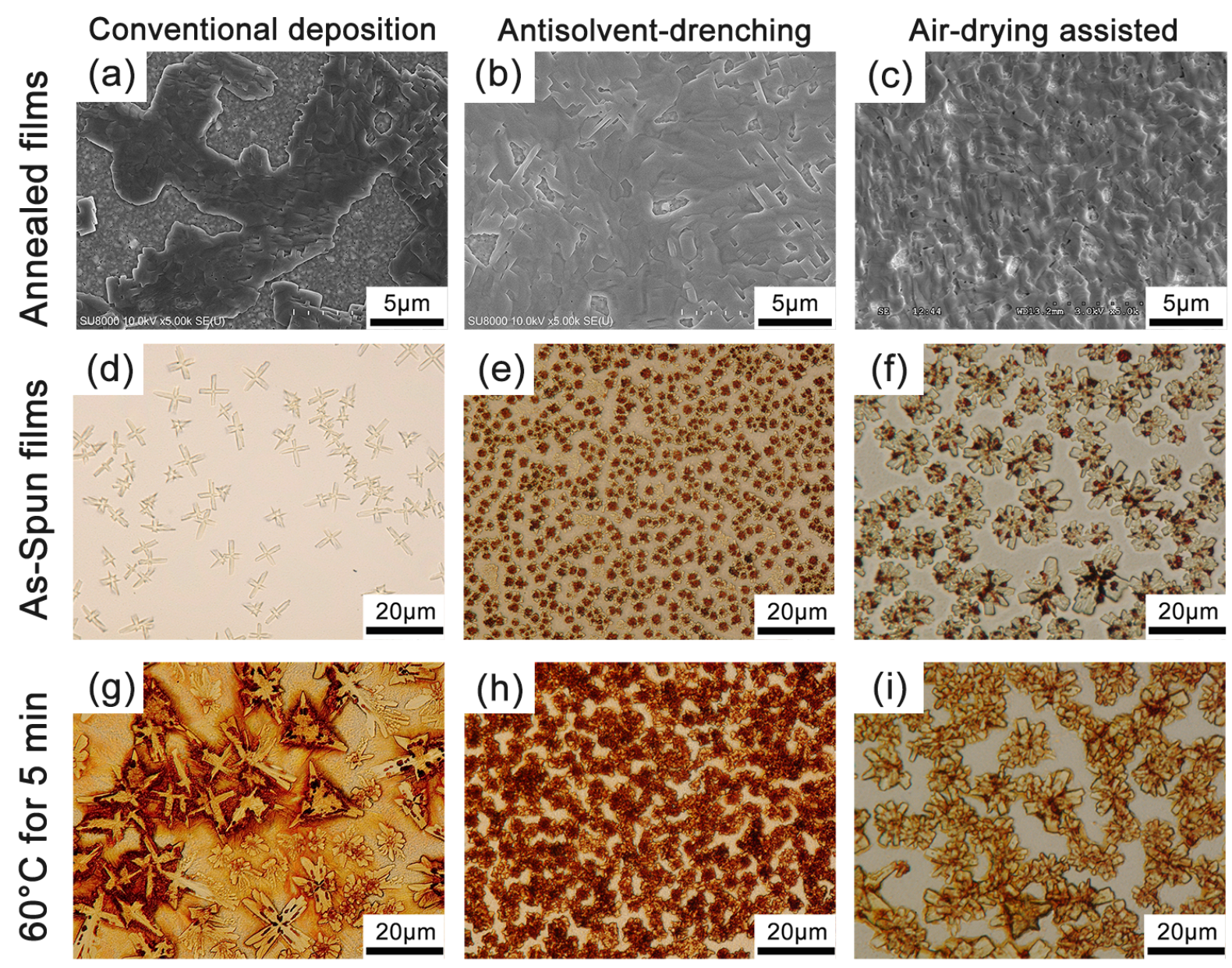

Figure 2: SEM images of perovskite films deposited from different methods: conventional deposition (a), antisolvent-drenching (b) and air-drying assisted deposition (c); optical micrographs taken during the in situ thermal annealing of perovskite films from different deposition processes after spin-coating and anneal at $60{ }^{\circ} \mathrm{C}$ for $5 \mathrm{~min}$ : conventional deposition $(\mathrm{d}, \mathrm{g})$, antisolvent-drenching (e, h) and air-drying assisted deposition (f, i). 
(a)

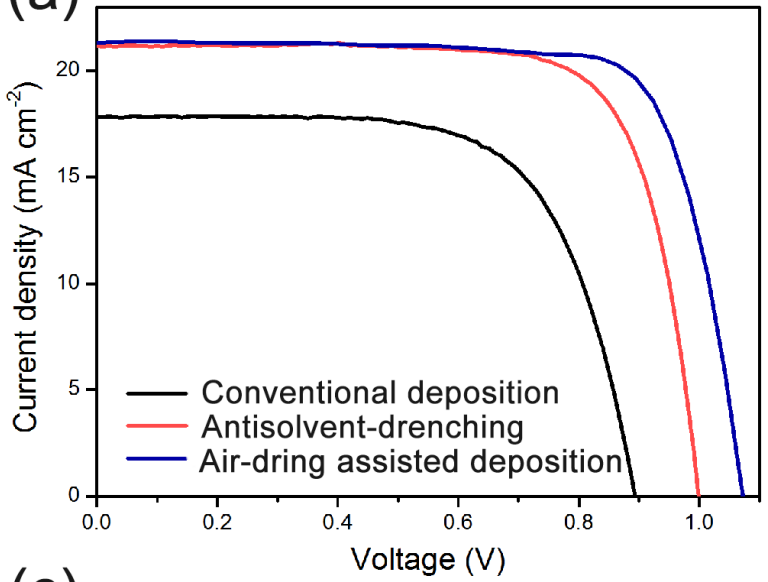

(c)

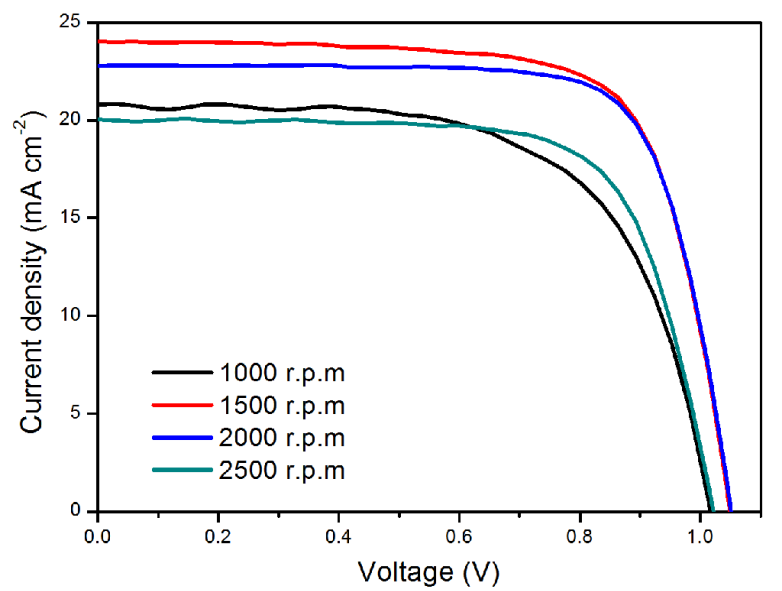

(b)

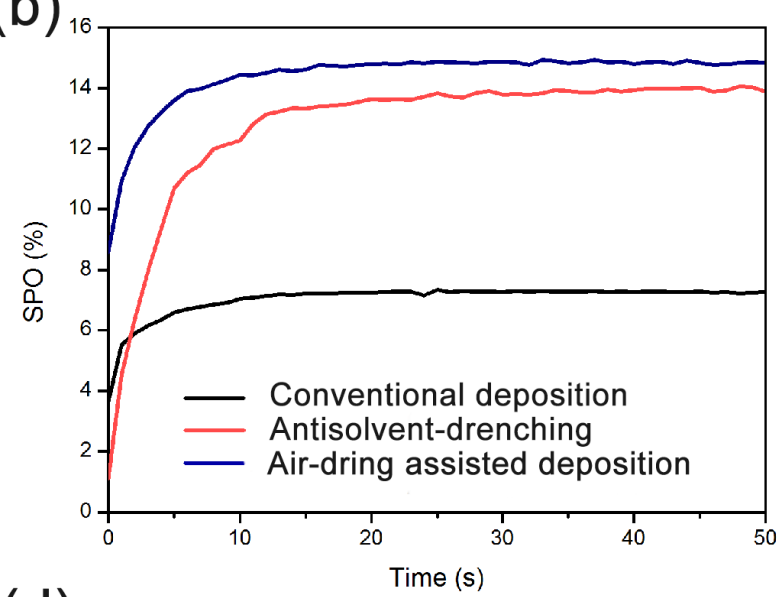

(d)

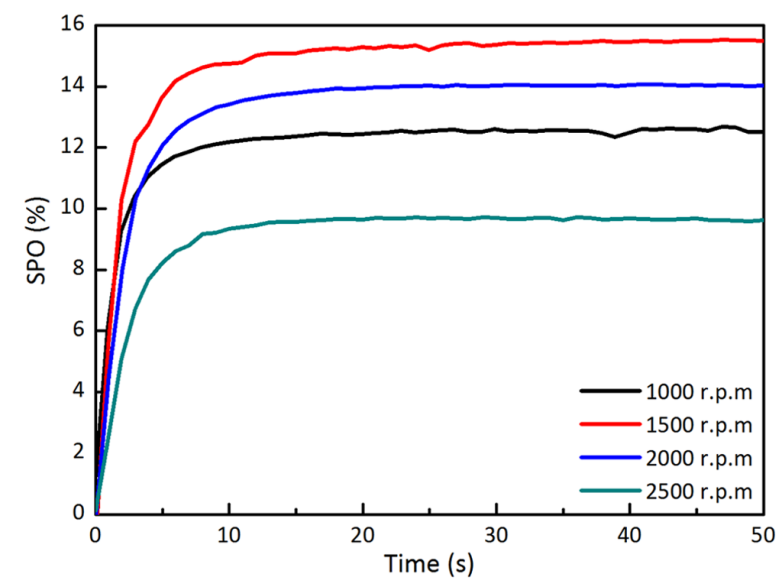

Figure 3: J-V curves (a) and stabilized power output (b) for perovskite solar cells in which the perovskite layer was deposited from conventional deposition, antisolvent-drenching and air-drying assisted deposition; J-V characteristics (c) and stabilized power output (d) of optimized perovskite solar cells with $\mathrm{C}_{60}$ layers deposited at different spin-coating speed. 
(a)
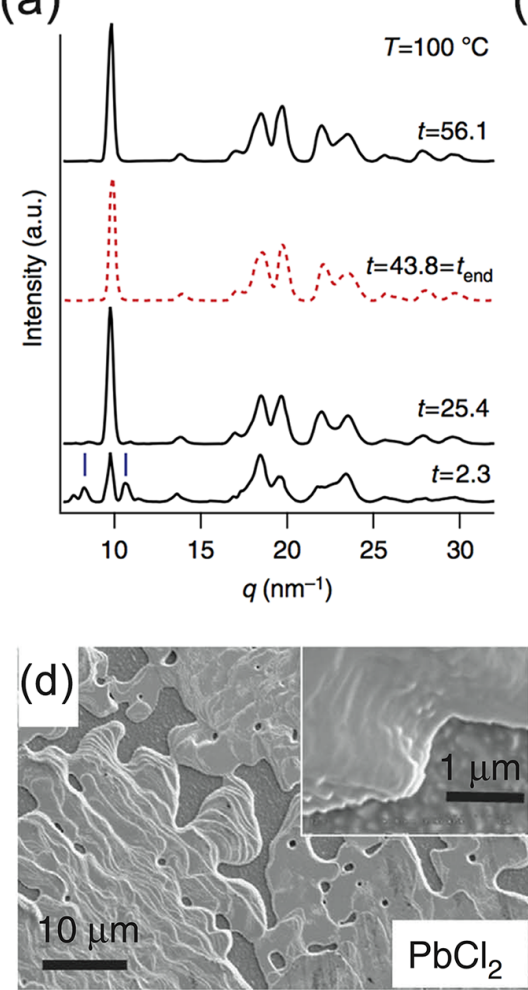

(b)

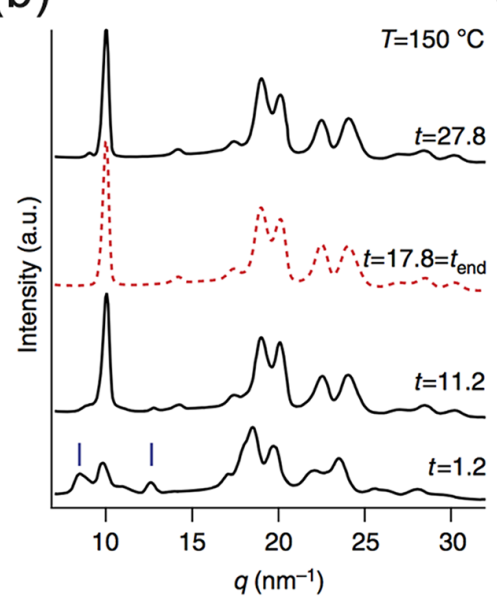

(c)

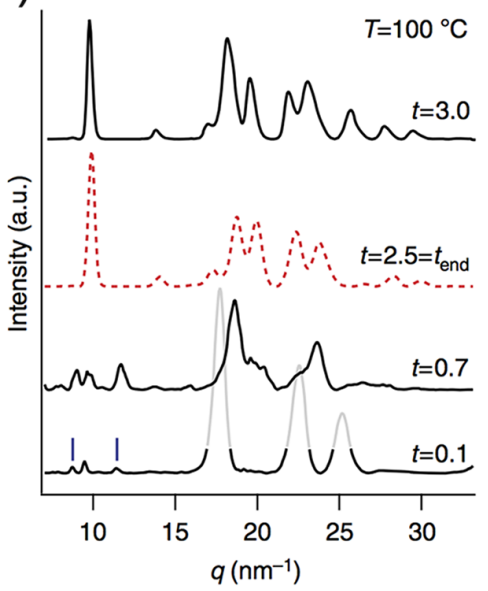

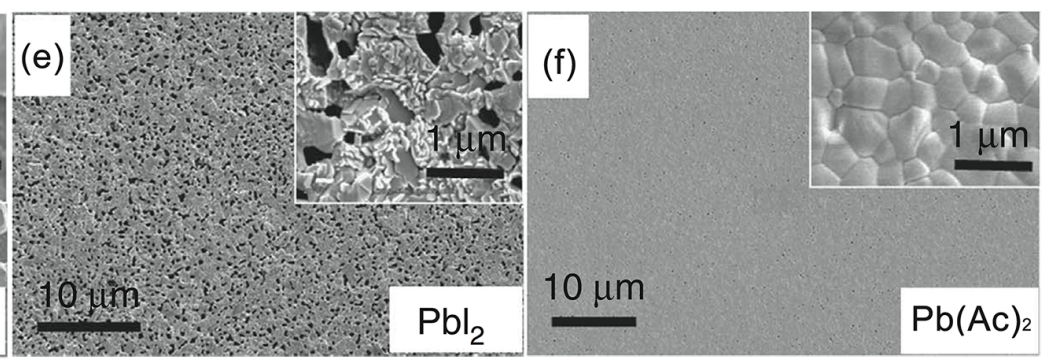

Figure 4: Azimuthally integrated 1D plots at several key time points ( $t$, in minutes) of annealing for films made from (a) $\mathrm{PbCl}_{2}$, (b) $\mathrm{PbI}_{2}$, and (c) $\mathrm{Pb}(\mathrm{Ac})_{2} \cdot 3 \mathrm{H}_{2} \mathrm{O}$ routes; SEM images of perovskite films deposited compact $\mathrm{TiO}_{2}$ coated FTO substrates from three different lead sources $\mathrm{PbCl}_{2}(\mathrm{~d}), \mathrm{PbI}_{2}(\mathrm{e})$ and $\mathrm{Pb}(\mathrm{Ac})_{2} \cdot 3 \mathrm{H}_{2} \mathrm{O}$ (f), (insets show images with higher resolution). (Reproduced with permission. ${ }^{33}$ Copyright 2015, Nature Publishing Group.) 
(a)

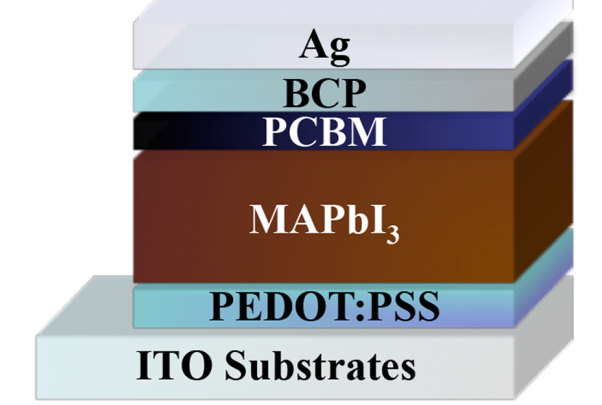

(c)

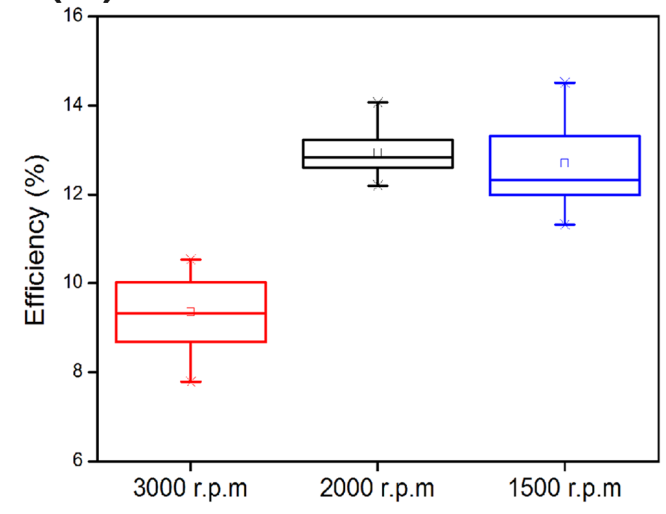

(b)

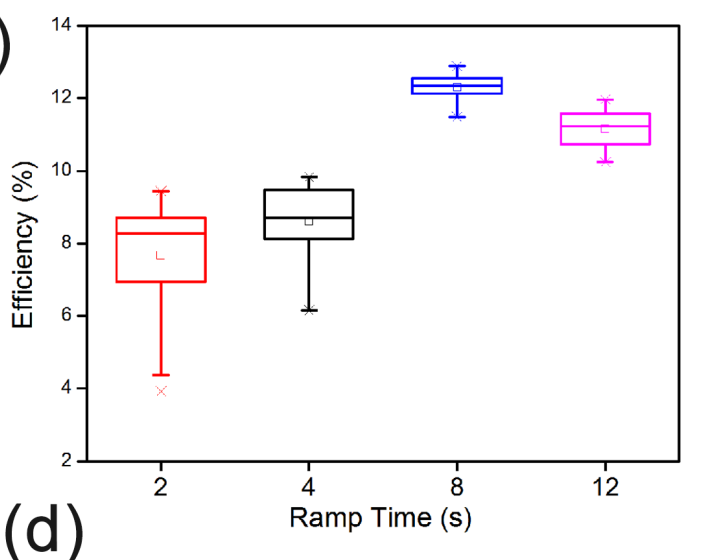

(d)

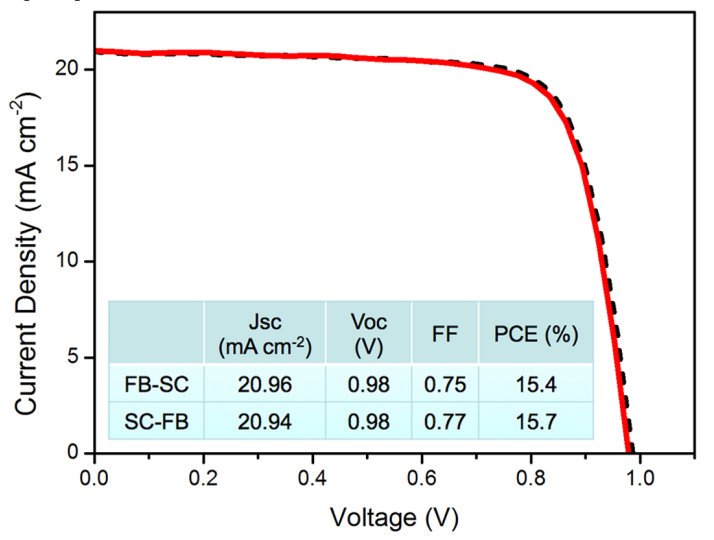

Figure 5. (a) Illustration of our inverted p-i-n planar device structure. Device efficiency fabricated from $40 \mathrm{wt} \%$ precursor with different ramp time (b) and different spin-coating speed (c). (d) Device performance of optimized inverted planar solar cell based on perovskite film deposited from $\mathrm{Pb}(\mathrm{Ac})_{2} \cdot 3 \mathrm{H}_{2} \mathrm{O}$ precursors. J-V curves measured from forward bias (FB) (black dash line) to short-circuit (SC) and back again (red solid line) exhibit no observable hysteresis. 
(a)
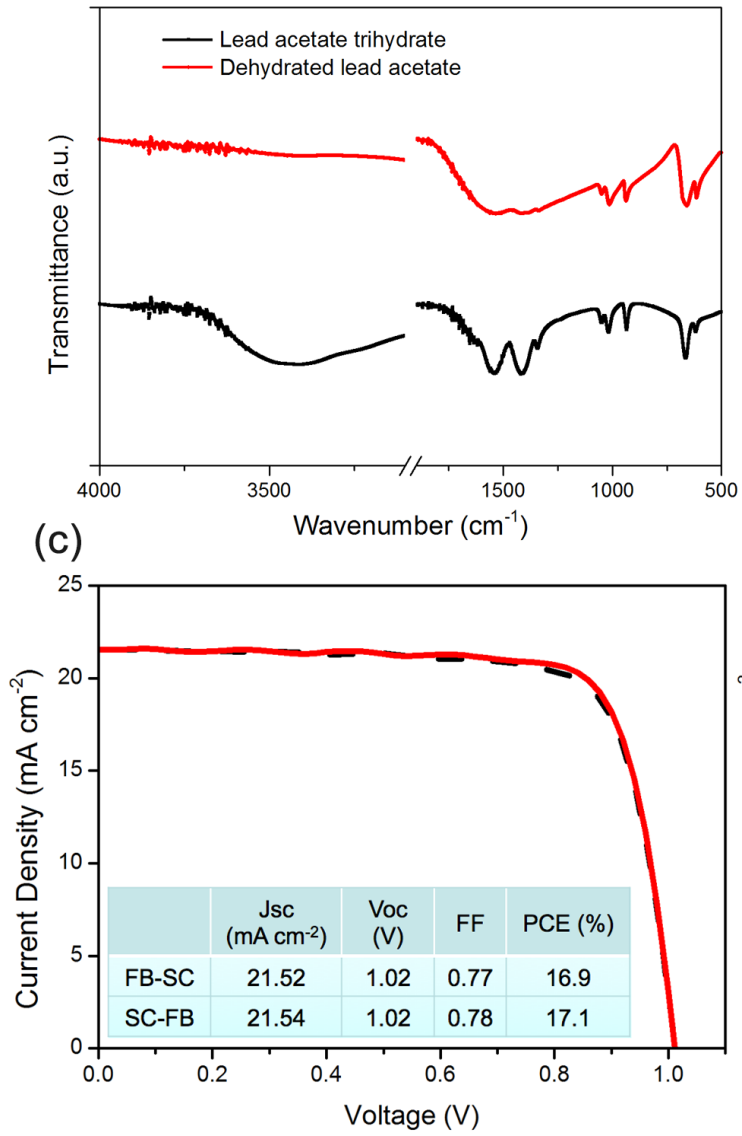

(b)

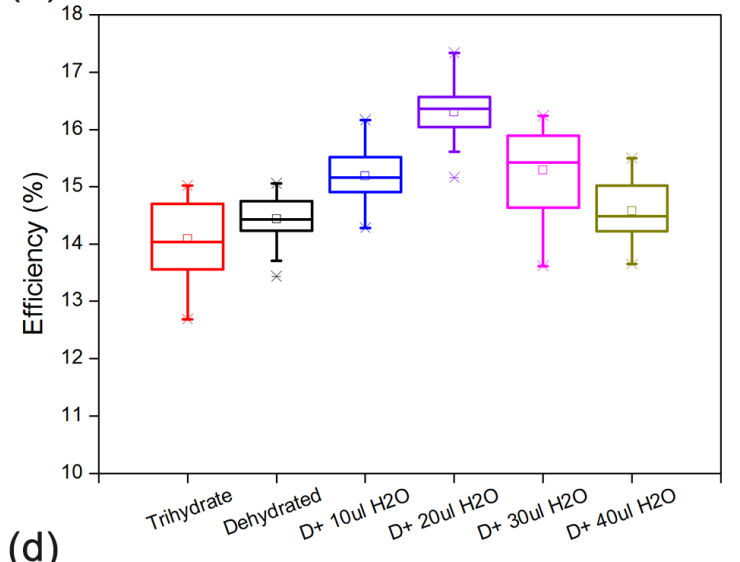

(d)

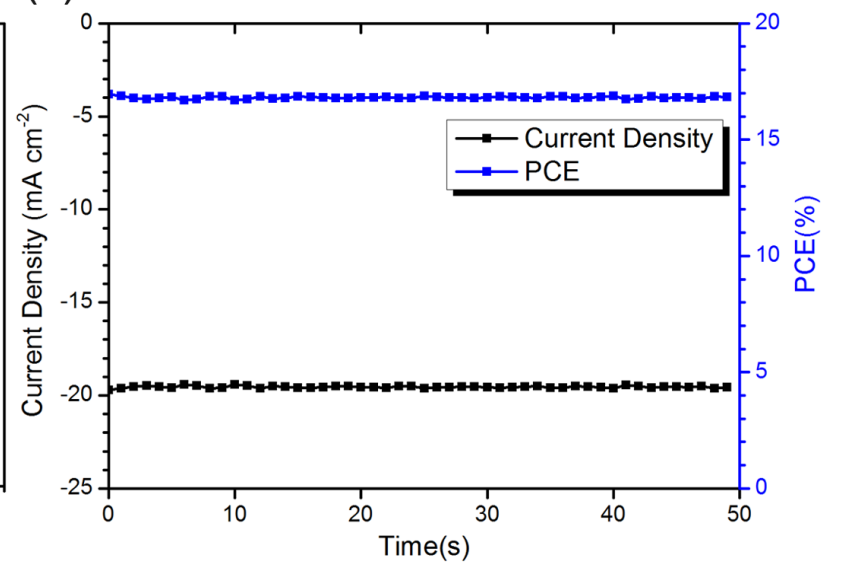

Figure 6. (a) FTIR spectra of the lead acetate trihydrate and dehydrated lead acetate synthesized from the reaction with acetic anhydride; (b) Efficiency of devices derived from precursor composed of $\mathrm{Pb}(\mathrm{Ac})_{2} \cdot 3 \mathrm{H}_{2} \mathrm{O}$, dehydrated $\mathrm{Pb}(\mathrm{Ac})_{2}$ with different amount of water. J-V curves (FB-SC black dash line, SC-FB red solid line) (c) and stabilized power output efficiency and photocurrent (at $0.86 \mathrm{~V}$ ) for the champion device fabricated from dehydrated $\mathrm{Pb}(\mathrm{Ac})_{2}$ with optimized water content. 


\section{References:}

[1] Green, M. A.; Ho-Baillie, A.; Snaith, H. J. The emergence of perovskite solar cells. Nat. Photonics 2014, 8, 506-514.

[2] Zhang, W.; Eperon, G. E.; Snaith, H. J. Metal halide perovskites for energy applications. Nat. Energy 2016, 1, 16048.

[3] Stranks, S. D.; Snaith, H. J. Metal-halide perovskites for photovoltaic and light-emitting devices. Nat. Nanotechnol. 2015, 10, 391-402.

[4] Luo, J.; Im, J.-H.; Mayer, M. T.; Schreier, M.; Nazeeruddin, M. K.; Park, N.-G.; Tilley, S. D.; Fan, H. J.; Grätzel, M. Water photolysis at $12.3 \%$ efficiency via perovskite photovoltaics and Earth-abundant catalysts. Science 2014, 345, 1593-1596.

[5] Xing, G.; Mathews, N.; Lim, S. S.; Yantara, N.; Liu, X.; Sabba, D.; Grätzel, M.; Mhaisalkar, S.; Sum, T. C. Low-temperature solution-processed wavelength-tunable perovskites for lasing. Nat. Mater. 2014, 13, 476-480.

[6] Tan, Z.-K.; Moghaddam, R. S.; Lai, M. L.; Docampo, P.; Higler, R.; Deschler, F.; Price, M.; Sadhanala, A.; Pazos, L. M.; Credgington, D., et al. Bright light-emitting diodes based on organometal halide perovskite. Nat. Nanotechnol. 2014, 9, 687-692.

[7] Noh, J. H.; Im, S. H.; Heo, J. H.; Mandal, T. N.; Seok, S. I. Chemical Management for Colorful, Efficient, and Stable Inorganic-Organic Hybrid Nanostructured Solar Cells. Nano Lett. 2013, 13, 1764-1769.

[8] Shi, D.; Adinolfi, V.; Comin, R.; Yuan, M.; Alarousu, E.; Buin, A.; Chen, Y.; Hoogland, S.; Rothenberger, A.; Katsiev, K., et al. Low trap-state density and long carrier diffusion in organolead trihalide perovskite single crystals. Science 2015, 347, 519-522.

[9] Eperon, G. E.; Stranks, S. D.; Menelaou, C.; Johnston, M. B.; Herz, L. M.; Snaith, H. J. Formamidinium lead trihalide: a broadly tunable perovskite for efficient planar heterojunction solar cells. Energy Environ. Sci. 2014, 7, 982-988.

[10]Dong, Q.; Fang, Y.; Shao, Y.; Mulligan, P.; Qiu, J.; Cao, L.; Huang, J. Electron-hole diffusion lengths $>175 \mu \mathrm{m}$ in solution-grown $\mathrm{CH}_{3} \mathrm{NH}_{3} \mathrm{PbI}_{3}$ single crystals. Science 2015, 347, 967-970.

[11]Stranks, S. D.; Eperon, G. E.; Grancini, G.; Menelaou, C.; Alcocer, M. J. P.; Leijtens, T.; Herz, L. M.; Petrozza, A.; Snaith, H. J. Electron-Hole Diffusion Lengths Exceeding 1 Micrometer in an Organometal Trihalide Perovskite Absorber. Science 2013, 342, 341-344.

[12]Xing, G.; Mathews, N.; Sun, S.; Lim, S. S.; Lam, Y. M.; Grätzel, M.; Mhaisalkar, S.; Sum, T. C. Long-Range Balanced Electron- and Hole-Transport Lengths in Organic-Inorganic $\mathrm{CH}_{3} \mathrm{NH}_{3} \mathrm{PbI}_{3}$. Science 2013, 342, 344-347.

[13]Kojima, A.; Teshima, K.; Shirai, Y.; Miyasaka, T. Organometal Halide Perovskites as Visible-Light Sensitizers for Photovoltaic Cells. J. Am. Chem. Soc 2009, 131, 6050-6051.

[14]Jeon, N. J.; Noh, J. H.; Kim, Y. C.; Yang, W. S.; Ryu, S.; Seok, S. I. Solvent engineering for high-performance inorganic-organic hybrid perovskite solar cells. Nat. Mater. 2014, 13, 897-903.

[15]Yang, W. S.; Noh, J. H.; Jeon, N. J.; Kim, Y. C.; Ryu, S.; Seo, J.; Seok, S. I. High-performance photovoltaic perovskite layers fabricated through intramolecular exchange. Science 2015, 348, 1234-1237. 
[16]Jeon, N. J.; Noh, J. H.; Yang, W. S.; Kim, Y. C.; Ryu, S.; Seo, J.; Seok, S. I. Compositional engineering of perovskite materials for high-performance solar cells. Nature 2015, 517, 476-480.

[17]McMeekin, D. P.; Sadoughi, G.; Rehman, W.; Eperon, G. E.; Saliba, M.; Hörantner, M. T.; Haghighirad, A.; Sakai, N.; Korte, L.; Rech, B., et al. A mixed-cation lead mixed-halide perovskite absorber for tandem solar cells. Science 2016, 351, 151-155.

[18]Li, X.; Bi, D.; Yi, C.; Décoppet, J.-D.; Luo, J.; Zakeeruddin, S. M.; Hagfeldt, A.; Grätzel, M. A vacuum flash-assisted solution process for high-efficiency large-area perovskite solar cells. Science 2016.

[19]Burschka, J.; Pellet, N.; Moon, S.-J.; Humphry-Baker, R.; Gao, P.; Nazeeruddin, M. K.; Gratzel, M. Sequential deposition as a route to high-performance perovskite-sensitized solar cells. Nature 2013, 499, 316-319.

[20] http://www.nrel.gov/ncpv/images/efficiency_chart.jpg.

[21]Im, J.-H.; Lee, C.-R.; Lee, J.-W.; Park, S.-W.; Park, N.-G. 6.5\% efficient perovskite quantum-dot-sensitized solar cell. Nanoscale 2011, 3, 4088-4093.

[22]Lee, M. M.; Teuscher, J.; Miyasaka, T.; Murakami, T. N.; Snaith, H. J. Efficient Hybrid Solar Cells Based on Meso-Superstructured Organometal Halide Perovskites. Science 2012, 338, 643-647.

[23]Kim, H.-S.; Lee, C.-R.; Im, J.-H.; Lee, K.-B.; Moehl, T.; Marchioro, A.; Moon, S.-J.; Humphry-Baker, R.; Yum, J.-H.; Moser, J. E., et al. Lead Iodide Perovskite Sensitized All-Solid-State Submicron Thin Film Mesoscopic Solar Cell with Efficiency Exceeding 9\%. Sci. Rep. 2012, 2, 591.

[24]Ball, J. M.; Lee, M. M.; Hey, A.; Snaith, H. J. Low-temperature processed meso-superstructured to thin-film perovskite solar cells. Energy Environ. Sci. 2013, 6, $1739-1743$.

[25]Liu, M.; Johnston, M. B.; Snaith, H. J. Efficient planar heterojunction perovskite solar cells by vapour deposition. Nature 2013, 501, 395-398.

[26]Eperon, G. E.; Burlakov, V. M.; Docampo, P.; Goriely, A.; Snaith, H. J. Morphological Control for High Performance, Solution-Processed Planar Heterojunction Perovskite Solar Cells. Adv. Funct. Mater. 2014, 24, 151-157.

[27]Wang, Y.; Bai, S.; Cheng, L.; Wang, N.; Wang, J.; Gao, F.; Huang, W. High-Efficiency Flexible Solar Cells Based on Organometal Halide Perovskites. Adv. Mater. 2016, 28, 4532-4540.

[28]Kaltenbrunner, M.; Adam, G.; Glowacki, E. D.; Drack, M.; Schwodiauer, R.; Leonat, L.; Apaydin, D. H.; Groiss, H.; Scharber, M. C.; White, M. S., et al. Flexible high power-per-weight perovskite solar cells with chromium oxide-metal contacts for improved stability in air. Nat. Mater. 2015, 14, 1032-1039.

[29]Xiao, M.; Huang, F.; Huang, W.; Dkhissi, Y.; Zhu, Y.; Etheridge, J.; Gray-Weale, A.; Bach, U.; Cheng, Y.-B.; Spiccia, L. A Fast Deposition-Crystallization Procedure for Highly Efficient Lead Iodide Perovskite Thin-Film Solar Cells. Angew. Chem. Int. Ed. 2014, 126, 10056-10061.

[30]Xiao, Z.; Bi, C.; Shao, Y.; Dong, Q.; Wang, Q.; Yuan, Y.; Wang, C.; Gao, Y.; Huang, J. Efficient, high yield perovskite photovoltaic devices grown by interdiffusion of 
solution-processed precursor stacking layers. Energy Environ. Sci. 2014, 7, 2619-2623.

[31]Jeng, J.-Y.; Chiang, Y.-F.; Lee, M.-H.; Peng, S.-R.; Guo, T.-F.; Chen, P.; Wen, T.-C. $\mathrm{CH} 3 \mathrm{NH} 3 \mathrm{PbI} 3$ Perovskite/Fullerene Planar-Heterojunction Hybrid Solar Cells. Adv. Mater. 2013, 25, 3727-3732.

[32]Zhang, W.; Pathak, S.; Sakai, N.; Stergiopoulos, T.; Nayak, P. K.; Noel, N. K.; Haghighirad, A. A.; Burlakov, V. M.; deQuilettes, D. W.; Sadhanala, A., et al. Enhanced optoelectronic quality of perovskite thin films with hypophosphorous acid for planar heterojunction solar cells. Nat. Commun. 2015, 6, 10030.

[33]Zhang, W.; Saliba, M.; Moore, D. T.; Pathak, S. K.; Hörantner, M. T.; Stergiopoulos, T.; Stranks, S. D.; Eperon, G. E.; Alexander-Webber, J. A.; Abate, A., et al. Ultrasmooth organic-inorganic perovskite thin-film formation and crystallization for efficient planar heterojunction solar cells. Nat. Commun. 2015, 6, 6142.

[34]Bi, C.; Wang, Q.; Shao, Y.; Yuan, Y.; Xiao, Z.; Huang, J. Non-wetting surface-driven high-aspect-ratio crystalline grain growth for efficient hybrid perovskite solar cells. Nat. Commun. 2015, 6, 7747.

[35]Docampo, P.; Ball, J. M.; Darwich, M.; Eperon, G. E.; Snaith, H. J. Efficient organometal trihalide perovskite planar-heterojunction solar cells on flexible polymer substrates. Nat. Commun. 2013, 4, 2761.

[36]Eperon, G. E.; Habisreutinger, S. N.; Leijtens, T.; Bruijnaers, B. J.; van Franeker, J. J.; deQuilettes, D. W.; Pathak, S.; Sutton, R. J.; Grancini, G.; Ginger, D. S., et al. The Importance of Moisture in Hybrid Lead Halide Perovskite Thin Film Fabrication. ACS Nano 2015, 9, 9380-9393.

[37]Yu, H.; Wang, F.; Xie, F.; Li, W.; Chen, J.; Zhao, N. The Role of Chlorine in the Formation Process of " $\mathrm{CH}_{3} \mathrm{NH}_{3} \mathrm{PbI}_{3-\mathrm{x}} \mathrm{Cl}_{\mathrm{x}}$ " Perovskite. Adv. Funct. Mater. 2014, 24, 7102-7108.

[38]Zhou, H.; Chen, Q.; Li, G.; Luo, S.; Song, T.-b.; Duan, H.-S.; Hong, Z.; You, J.; Liu, Y.; Yang, Y. Interface engineering of highly efficient perovskite solar cells. Science 2014, $345,542-546$.

[39] Sakai, N.; Pathak, S.; Chen, H.-W.; Haghighirad, A. A.; Stranks, S. D.; Miyasaka, T.; Snaith, H. J. The mechanism of toluene-assisted crystallization of organic-inorganic perovskites for highly efficient solar cells. J. Mater. Chem. A 2016, 4, 4464-4471.

[40]Tan, K. W.; Moore, D. T.; Saliba, M.; Sai, H.; Estroff, L. A.; Hanrath, T.; Snaith, H. J.; Wiesner, U. Thermally Induced Structural Evolution and Performance of Mesoporous Block Copolymer-Directed Alumina Perovskite Solar Cells. ACS Nano 2014, 8, 4730-4739.

[41] Snaith, H. J.; Abate, A.; Ball, J. M.; Eperon, G. E.; Leijtens, T.; Noel, N. K.; Stranks, S. D.; Wang, J. T.-W.; Wojciechowski, K.; Zhang, W. Anomalous Hysteresis in Perovskite Solar Cells. J. Phys. Chem. Lett. 2014, 5, 1511-1515.

[42]Zhang, Y.; Liu, M.; Eperon, G. E.; Leijtens, T. C.; McMeekin, D.; Saliba, M.; Zhang, W.; de Bastiani, M.; Petrozza, A.; Herz, L. M., et al. Charge selective contacts, mobile ions and anomalous hysteresis in organic-inorganic perovskite solar cells. Mater. Horiz. 2015, 2, 315-322.

[43]Unger, E. L.; Hoke, E. T.; Bailie, C. D.; Nguyen, W. H.; Bowring, A. R.; Heumuller, T.; Christoforo, M. G.; McGehee, M. D. Hysteresis and transient behavior in current-voltage 
measurements of hybrid-perovskite absorber solar cells. Energy Environ. Sci. 2014, 7, 3690-3698.

[44]Dualeh, A.; Moehl, T.; Tétreault, N.; Teuscher, J.; Gao, P.; Nazeeruddin, M. K.; Grätzel, M. Impedance Spectroscopic Analysis of Lead Iodide Perovskite-Sensitized Solid-State Solar Cells. ACS Nano 2014, 8, 362-373.

[45]Leijtens, T.; Eperon, G. E.; Pathak, S.; Abate, A.; Lee, M. M.; Snaith, H. J. Overcoming ultraviolet light instability of sensitized $\mathrm{TiO}_{2}$ with meso-superstructured organometal tri-halide perovskite solar cells. Nat. Commun. 2013, 4, 2885.

[46]Abrusci, A.; Stranks, S. D.; Docampo, P.; Yip, H.-L.; Jen, A. K. Y.; Snaith, H. J. High-Performance Perovskite-Polymer Hybrid Solar Cells via Electronic Coupling with Fullerene Monolayers. Nano Lett. 2013, 13, 3124-3128.

[47]Tao, C.; Neutzner, S.; Colella, L.; Marras, S.; Srimath Kandada, A. R.; Gandini, M.; Bastiani, M. D.; Pace, G.; Manna, L.; Caironi, M., et al. 17.6\% stabilized efficiency in low-temperature processed planar perovskite solar cells. Energy Environ. Sci. 2015, 8, 2365-2370.

[48]Wojciechowski, K.; Leijtens, T.; Siprova, S.; Schlueter, C.; Hörantner, M. T.; Wang, J. T.-W.; Li, C.-Z.; Jen, A. K. Y.; Lee, T.-L.; Snaith, H. J. C 60 as an Efficient n-Type Compact Layer in Perovskite Solar Cells. J. Phys. Chem. Lett. 2015, 6, 2399-2405.

[49]Wojciechowski, K.; Stranks, S. D.; Abate, A.; Sadoughi, G.; Sadhanala, A.; Kopidakis, N.; Rumbles, G.; Li, C.-Z.; Friend, R. H.; Jen, A. K. Y., et al. Heterojunction Modification for Highly Efficient Organic-Inorganic Perovskite Solar Cells. ACS Nano 2014, 8, 12701-12709.

[50]Wojciechowski, K.; Ramirez, I.; Gorisse, T.; Dautel, O.; Dasari, R.; Sakai, N.; Hardigree, J. M.; Song, S.; Marder, S.; Riede, M., et al. Cross-Linkable Fullerene Derivatives for Solution-Processed n-i-p Perovskite Solar Cells. ACS Energy Lett. 2016, 1, 648-653.

[51]Moore, D. T.; Sai, H.; Tan, K. W.; Smilgies, D.-M.; Zhang, W.; Snaith, H. J.; Wiesner, U.; Estroff, L. A. Crystallization Kinetics of Organic-Inorganic Trihalide Perovskites and the Role of the Lead Anion in Crystal Growth. J. Am. Chem. Soc 2015, 137, 2350-2358.

[52]Shao, Y.; Xiao, Z.; Bi, C.; Yuan, Y.; Huang, J. Origin and elimination of photocurrent hysteresis by fullerene passivation in $\mathrm{CH}_{3} \mathrm{NH}_{3} \mathrm{PbI}_{3}$ planar heterojunction solar cells. Nat. Commun. 2014, 5, 5784.

[53]Bai, S.; Wu, Z.; Wu, X.; Jin, Y.; Zhao, N.; Chen, Z.; Mei, Q.; Wang, X.; Ye, Z.; Song, T., et al. High-performance planar heterojunction perovskite solar cells: Preserving long charge carrier diffusion lengths and interfacial engineering. Nano Res. 2014, 7, 1749-1758.

[54]Wang, J. T.-W.; Wang, Z.; Pathak, S.; Zhang, W.; deQuilettes, D. W.; Wisnivesky-Rocca-Rivarola, F.; Huang, J.; Nayak, P. K.; Patel, J. B.; Mohd Yusof, H. A., et al. Efficient perovskite solar cells by metal ion doping. Energy Environ. Sci. 2016, 9, 2892-2901.

[55]Huang, F.; Dkhissi, Y.; Huang, W.; Xiao, M.; Benesperi, I.; Rubanov, S.; Zhu, Y.; Lin, X.; Jiang, L.; Zhou, Y., et al. Gas-assisted preparation of lead iodide perovskite films consisting of a monolayer of single crystalline grains for high efficiency planar solar cells. 
Nano Energy 2014, 10, 10-18.

[56]Conings, B.; Drijkoningen, J.; Gauquelin, N.; Babayigit, A.; D'Haen, J.; D'Olieslaeger, L.; Ethirajan, A.; Verbeeck, J.; Manca, J.; Mosconi, E., et al. Intrinsic Thermal Instability of Methylammonium Lead Trihalide Perovskite. Adv. Energy Mater. 2015, 5, n/a-n/a.

[57] Shao, Y.; Yuan, Y.; Huang, J. Correlation of energy disorder and open-circuit voltage in hybrid perovskite solar cells. Nat. Energy 2016, 1, 15001.

[58]Chen, W.; Wu, Y.; Liu, J.; Qin, C.; Yang, X.; Islam, A.; Cheng, Y.-B.; Han, L. Hybrid interfacial layer leads to solid performance improvement of inverted perovskite solar cells. Energy Environ. Sci. 2015, 8, 629-640.

[59]Xu, J.; Buin, A.; Ip, A. H.; Li, W.; Voznyy, O.; Comin, R.; Yuan, M.; Jeon, S.; Ning, Z.; McDowell, J. J., et al. Perovskite-fullerene hybrid materials suppress hysteresis in planar diodes. Nat. Commun. 2015, 6, 7081.

[60]Qing, J.; Chandran, H.-T.; Cheng, Y.-H.; Liu, X.-K.; Li, H.-W.; Tsang, S.-W.; Lo, M.-F.; Lee, C.-S. Chlorine Incorporation for Enhanced Performance of Planar Perovskite Solar Cell Based on Lead Acetate Precursor. ACS Appl. Mater. Interfaces 2015, 7, $23110-23116$.

[61]Bush, K. A.; Bailie, C. D.; Chen, Y.; Bowring, A. R.; Wang, W.; Ma, W.; Leijtens, T.; Moghadam, F.; McGehee, M. D. Thermal and Environmental Stability of Semi-Transparent Perovskite Solar Cells for Tandems Enabled by a Solution-Processed Nanoparticle Buffer Layer and Sputtered ITO Electrode. Adv. Mater. 2016, 28, 3937-3943.

[62]Xu, J.; Voznyy, O.; Comin, R.; Gong, X.; Walters, G.; Liu, M.; Kanjanaboos, P.; Lan, X.; Sargent, E. H. Crosslinked Remote-Doped Hole-Extracting Contacts Enhance Stability under Accelerated Lifetime Testing in Perovskite Solar Cells. Adv. Mater. 2016, 28, 2807-2815.

[63]Yanovskaya, M. I.; Obvintseva, I. E.; Solovyova, L. I.; Kovsman, E. P.; Vorotilov, K. A.; Vasilyev, V. A. Alkoxy-derived ferroelectric PZT films: The effect of lead acetate dehydration techniques and lead content in the electrochemically prepared solutions on the properties of the films. Integr. Ferroelectr. 1998, 19, 193-209.

[64]Gong, X.; Li, M.; Shi, X.-B.; Ma, H.; Wang, Z.-K.; Liao, L.-S. Controllable Perovskite Crystallization by Water Additive for High-Performance Solar Cells. Adv. Funct. Mater. 2015, 25, 6671-6678.

[65]Wu, C.-G.; Chiang, C.-H.; Tseng, Z.-L.; Nazeeruddin, M. K.; Hagfeldt, A.; Gratzel, M. High efficiency stable inverted perovskite solar cells without current hysteresis. Energy Environ. Sci. 2015, 8, 2725-2733.

[66]Conings, B.; Babayigit, A.; Vangerven, T.; D'Haen, J.; Manca, J.; Boyen, H.-G. The impact of precursor water content on solution-processed organometal halide perovskite films and solar cells. J. Mater. Chem. A 2015, 3, 19123-19128.

[67]Ling, L.; Yuan, S.; Wang, P.; Zhang, H.; Tu, L.; Wang, J.; Zhan, Y.; Zheng, L. Precisely Controlled Hydration Water for Performance Improvement of Organic-Inorganic Perovskite Solar Cells. Adv. Funct. Mater. 2016, 26, 5028-5034. 
Table of Contents (ToC) Graphic:

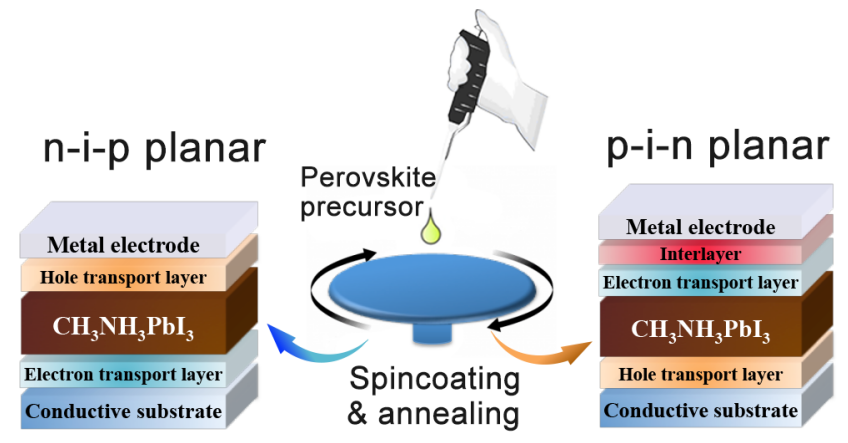

